Marcin Czerwiński

\title{
Udział konsorcjum w postępowaniu o udzielenie zamówienia publicznego na przykładzie Polski, Wielkiej Brytanii i Francji
}

\section{Uwagi wprowadzające}

W niniejszym opracowaniu zostanie przedstawiony kształt regulacji dotyczącej udziału konsorcjum w postępowaniu zamówieniowym obowiązującej na obszarze trzech państw Unii Europejskiej: Polski, Wielkiej Brytanii i Francji. Choć nie sposób znaleźć definicji konsorcjum adekwatnej dla wszystkich państw Unii Europejskiej, to ze względu na harmonizację przepisów dotyczących funkcjonowania rynku zamówień publicznych przyjęte przez państwa rozwiązania są dość zbliżone. Niemniej występują też pewne unormowania charakterystyczne dla poszczególnych krajów. Pojawia się więc pokusa, aby rozważyć sens przyjęcia podobnych rozwiązań w innych państwach.

Przy charakterystyce każdego z państw opisano najpierw ogólnie prawne aspekty funkcjonowania konsorcjum $\mathrm{w}$ danym systemie prawnym, a następnie przedstawiono instytucje podobne, jak spółka cywilna czy podwykonawstwo, by wreszcie scharakteryzować regulację odnoszącą się do udziału konsorcjum w postępowaniach o udzielenie zamówienia publicznego. Uznano za przydatne - przede wszystkim w części brytyjskiej - odwołanie się przy niektórych kwestiach problematycznych wprost do prawa unijnego i orzecznictwa Trybunału Sprawiedliwości Unii Europejskiej. Ze względu na obszerną literaturę dotyczącą funkcjonowania konsorcjum w Polsce, w tym funkcjonowania w obrocie regulowanym przez prawo zamówień publicznych, część dotycząca polskiej regulacji nie będzie miała charakteru wyczerpującego, a jednocześnie odsyłać będzie do literatury uzupełniającej, w której można znaleźć również analizę aktualnego orzecznictwa sądowego i Krajowej Izby Odwoławczej. W części brytyjskiej i francuskiej niektóre tezy będą wymagały weryfikacji w praktyce stosowania przepisów ze względu na dokonującą się zmianę stanu prawnego uwzględnioną w niniejszym opracowaniu. 


\section{Konsorcjum w polskim prawie zamówień publicznych}

\section{Konsorcjum w ogólności}

W polskim systemie prawnym konsorcjum postrzegane jest jako elastyczna forma kooperacji gospodarczej wypracowana na płaszczyźnie praktycznej. Nawiązanie stosunku konsorcjum może być podyktowane np. rozmiarem przedsięwzięcia koniecznego do wykonania oraz stopniem jego skomplikowania, który przerasta możliwości finansowe, organizacyjne czy techniczne pojedynczego podmiotu. Jednocześnie konsorcjum pozwala na niezależność konsorcjantów w pozostałych działaniach, niezwiązanych ze wspólnym przedsięwzięciem. Po osiągnięciu celu, dla którego utworzono konsorcjum, jest ono zazwyczaj rozwiązywane.

Brakuje w polskim prawie definicji konsorcjum czy umowy konsorcjalnej. Pojęć tych nie używają ani Kodeks cywilny ${ }^{1}$, ani Prawo zamówień publicznych ${ }^{2}$, ani ustawy podatkowe $^{3}$. O konsorcjum wspomina jedynie Prawo bankowe ${ }^{4}$, ustawa o zasadach finansowania nauki ${ }^{5}$, ustawa o ofercie publicznej ${ }^{6}$ oraz ustawa o niektórych umowach zawieranych w związku z realizacją zamówień o podstawowym znaczeniu dla bezpieczeństwa państwa $^{7}$, jednakże ustawy te nie regulują samej umowy konsorcjalnej. Dopuszczalność tworzenia przez kontrahentów tej formy współpracy wynika z zasady swobody umów (art. $353^{1}$ k.c.). Forma umowy konsorcjalnej może być dowolna (także ustna), choć ze względów dowodowych zazwyczaj będzie to forma pisemna.

W literaturze podkreśla się, że konsorcjum nie ma podmiotowości prawnej, nie posiada majątku odrębnego od majątku uczestników ani nie podlega rejestracji, tworzone jest przez zawarcie zobowiązaniowej umowy konsorcjalnej. Konsorcjanci zobowiązują się w umowie do wspólnego działania i ponoszenia ryzyka w celu urzeczywistnienia

1 Ustawa z dnia 23 kwietnia 1964 r. - Kodeks cywilny, t.j. Dz.U. 2014 poz. 121 ze zm.

2 Ustawa z dnia 29 stycznia 2004 r. - Prawo zamówień publicznych, t.j. Dz.U. 2013 poz. 907 ze zm., dalej p.z.p.

3 Zasadniczo konsorcja kwalifikowane są jako wspólne przedsięwzięcia w rozumieniu art. 5 ust. 1 ustawy z dnia 15 lutego 1992 r. o podatku dochodowym od osób prawnych, t.j. Dz.U. 2014 poz. 851 ze zm., i art. 8 ust. 1 ustawy z dnia 26 lipca 1991 r. o podatku dochodowym od osób fizycznych, t.j. Dz.U. 2012 poz. 361 ze zm.

4 Konsorcjum bankowe pojawia się w art. 73 § 1 ustawy z dnia 29 sierpnia 1997 r. - Prawo bankowe, t.j. Dz.U. 2012 poz. 1376.

5 Konsorcjum naukowe pojawia się w art. 2 pkt 12 ustawy z dnia 30 kwietnia 2010 r. o zasadach finansowania nauki, Dz.U. nr 96 poz. 615 ze zm.

6 Konsorcjum pojawia się w art. 14 ust. 3 ustawy z dnia 29 lipca 2005 r. o ofercie publicznej i warunkach wprowadzania instrumentów finansowych do zorganizowanego systemu obrotu oraz o spółkach publicznych, tj. Dz.U. 2013 poz. 1382 ze zm.

7 Konsorcjum pojawia się w art. 2 pkt 3 i art. 24 ustawy z 26 czerwca 2014 r. o niektórych umowach zawieranych w związku $\mathrm{z}$ realizacją zamówień o podstawowym znaczeniu dla bezpieczeństwa państwa, Dz.U. 2014 poz. 932. 
konkretnego przedsięwzięcia gospodarczego ${ }^{8}$. Stosunek ten jest o tyle specyficzny, że współdziałanie wspólników nie polega na wniesieniu wkładów, tylko na wykonaniu określonej części prac w należyty sposób . Dominuje pogląd, że umowy konsorcjalnej nie można kwalifikować jako umowy spółki cywilnej, chyba że konsorcjanci celowo ukształtują konsorcjum jako spółkę cywilną. Co istotne w praktyce, regulacje z zakresu rachunkowości ${ }^{10}$ czy ustawy o podatku od towarów i usług ${ }^{11}$ traktują spółkę cywilną inaczej niż prawo prywatne - jako odrębny podmiot, nie traktują natomiast w ten sam sposób umowy konsorcjum. Niektórzy autorzy opowiadają się za stosowaniem do umowy konsorcjalnej przepisów o spółce cywilnej w drodze analogii ${ }^{12}$, dostrzegając jednak odmienność konsorcjum względem spółki cywilnej w braku odpowiedzialności solidarnej konsorcjantów ${ }^{13}$. Należy też zauważyć, że dla umowy spółki wymagana jest forma pisemna pod rygorem ad probationem (art. 860 § 2 k.c.).

W praktyce najczęściej występują konsorcja zewnętrze, jednolite i scentralizowane. Oznacza to odpowiednio, że okoliczność zawarcia umowy kooperacyjnej jest jawna dla osób trzecich, występuje jedna wielostronna umowa konsorcjalna, a prowadzenie spraw oraz reprezentację konsorcjum powierza się jednemu z konsorcjantów, zwanemu liderem konsorcjum. W przypadku konsorcjum o charakterze wewnętrznym jego uczestnicy nie występują w stosunkach zewnętrznych wspólnie. Umowy z osobami trzecimi (np. inwestorem) zawiera tylko jeden z uczestników konsorcjum w imieniu własnym (ze skutkiem dla siebie albo na rachunek wszystkich konsorcjantów), tym samym samodzielnie ponosi on odpowiedzialność względem osób trzecich. Pozostali konsorcjanci są postrzegani na

8 L. Stecki, Konsorcjum, Toruń 1997; A. Opalski, Umowy o wspólne przedsięrzięcie (joint venture), [w:] System prawa prywatnego, t. 9, Prawo zobowiqzań - umowy nienazwane, red. W. Katner, Warszawa 2015, s. 877-885; S. Włodyka, M. Spyra, Umowy i porozumienia o wspótprace przedsiębiorców (umowy kooperacyjne), [w:] System prawa handlowego, t. 5, Prawo umów handlowych, red. S. Włodyka, Warszawa 2014, s. 707-718; S. Włodyka, Strategiczne umowy przedsiębiorców, Warszawa 2000, s. 245-269; J. Strzępka, Konsorcjum budowlane - wybrane zagadnienia prawne, „Monitor Prawniczy” 2012, nr 14, s. 738-744; J. Hilla, Prawne problemy funkcjonowania konsorcjum, „Radca Prawny” 2005, nr 5, s. 35-40.

9 E. Zielińska, Konsorcjum w procesie budowlanym w systemie polskiego i niemieckiego prawa prywatnego, w: Wptyw europeizacji prawa na instytucje prawa bandlowego, red. J. Kruczalak-Jankowska, Warszawa 2013, s. 586.

10 Art. 2 ust. 1 pkt 1 i 2 ustawy z dnia 29 września 1994 r. o rachunkowości, t.j. Dz.U. 2016 poz. 1047 ze zm.

11 Spółka cywilna jest jednostką organizacyjną w rozumieniu art. 15 ust. 1 ustawy z dnia 11 marca 2004 r. o podatku od towarów i usług (t.j. Dz.U. 2016 poz. 710), stąd konieczność rejestracji dla celów podatku VAT i uzyskanie numeru NIP.

12 A. Chrząszcz, Konsorcjum w zamówieniach publicznych, „Przegląd Prawa Handlowego” 2013, nr 7, s. 43.

13 Bezwzględnie wiążący art. 864 k.c. przewiduje solidarną odpowiedzialność wspólników spółki cywilnej. 
zewnątrz co najwyżej jako podwykonawcy, co jednak w przypadku umowy o roboty budowlane będzie pociągało za sobą konsekwencje $z$ art. $647^{1}$ k.c. ${ }^{14}$

Nie ma jednolitego modelu rozliczeń finansowych w konsorcjum i trudno przenosić na grunt tej konstrukcji rozwiązanie wprowadzone w art. 867 k.c. Dlatego sama umowa konsorcjalna powinna określać udział poszczególnych konsorcjantów w przychodach i kosztach przedsięwzięcia. W praktyce ustalenie tego udziału następuje metodą rzeczową lub finansową. W pierwszej bazuje się na zakresie rzeczowym robót realizowanych przez uczestnika, w efekcie czego każdy konsorcjant realizuje inny zysk zależny od własnych kosztów. W drugiej udział ten wyznacza się z góry przyjętym procentem w generowanych przychodach i kosztach, a zatem zysk jest dzielony między konsorcjantów w ustalonej proporcji ${ }^{15}$.

Skoro konsorcjum nie posiada podmiotowości prawnej, to tym samym nie ma zdolności procesowej. Stroną postępowania cywilnego albo administracyjnego są zawsze podmioty wchodzące w skład konsorcjum, a nie samo konsorcjum. Istotne wątpliwości wiążą się z dochodzeniem roszczeń przez konsorcjantów w postępowaniu sądowym. Uprawnienia do dochodzenia wynagrodzenia za świadczenia realizowane przez konsorcjum na rzecz podmiotów trzecich oraz innych roszczeń z tym związanych powinny być określone w umowie łączącej uczestników konsorcjum z kontrahentem zewnętrznym. Umowa taka może uwzględniać postanowienia umowy konsorcjalnej, ale jeśli przewiduje inne niż przyjęte w umowie konsorcjalnej reguły rozliczeń, to ma ona pierwszeństwo. Sądy muszą w każdym przypadku dokonywać oceny, czy między konsorcjantami zachodzi współuczestnictwo materialne zwykłe, czy współuczestnictwo konieczne. W pierwszym przypadku każdy konsorcjant mógłby występować z powództwem niezależnie od innych konsorcjantów. W drugim konsorcjanci tylko wspólnie mogliby dochodzić roszczenia od kontrahenta zewnętrznego (legitymacja procesowa łączna) ${ }^{16}$.

Konsorcjum jest strukturą względnie zamkniętą w tym sensie, że dopuszcza się w określonych wypadkach możliwość zwiększenia lub zmniejszenia liczby konsorcjantów oraz subrogację podmiotową, tj. wejście innego podmiotu w prawa i obowiązki konsorcjanta ${ }^{17}$.

\section{Regulacja udziału konsorcjum w postępowaniu zamówieniowym}

W praktyce konsorcja występują najczęściej w obrocie regulowanym przez prawo zamówień publicznych, przy czym w ustawie zamówieniowej pojęcie wykonawców występu-

14 Wymóg zgody inwestora na zaangażowanie podwykonawców i jego solidarna odpowiedzialność za zapłatę im wynagrodzenia.

15 K. Kańtor, K. Wróblewska, Umowa konsorcjum - konsekwencje w zakresie VAT, „Przegląd Podatkowy”2015, nr 12, s. 25.

16 J. May, Dochodzenie roszczeń przez uczestników konsorcjum, „Prawo Zamówień Publicznych” 2015, nr 2, s. 79.

17 L. Stecki, op. cit., s. 215-216. 
jących wspólnie pojawiło się dopiero w 2001 r. ${ }^{18}$ w odpowiedzi na dużą skale stosowania tej instytucji przez wykonawców ${ }^{19}$. Przed tą datą możliwość wspólnego ubiegania się o udzielenie zamówienia budziła wątpliwości w orzecznictwie ${ }^{20}$. Warto odnotować, że sytuacji konsorcjum w postępowaniu zamówieniowym poświęcono wiele miejsca w polskiej literaturze ${ }^{21}$.

Obecnie traktuje się konsorcjum jako instrument wsparcia małych i średnich przedsiębiorstw (MŚP) na rynku zamówieniowym² ${ }^{22}$. Wykonawcy wykorzystują konsorcjum

18 Ustawa z dnia 22 czerwca 2001 r. o zmianie ustawy o zamówieniach publicznych, Dz.U. nr 76 poz. 813.

19 Cf. np. wyrok Zespołu Arbitrów z dnia 19 marca 1998 r., UZP/ZO/0-108/98, ZPO 1998, nr 1, poz. 32; wyrok Zespołu Arbitrów z dnia 17 września 1998 r., UZP/ZO/0-756/98, ZPO 1998, nr 2, poz. 59; wyrok Zespołu Arbitrów z dnia 4 stycznia 1999 r., UZP/ZO/0-1185/98, www.uzp. gov.pl; wyrok Zespołu Arbitrów z dnia 12 stycznia 1999 r., UZP/ZO/0-1186/98, ZPO 1999, nr 1, poz.11; wyrok Zespołu Arbitrów z dnia 6 kwietnia 1999 r., UZP/ZO/0-162/99, ZPO 1999, nr 1, poz. 92; wyrok Zespołu Arbitrów z dnia 11 maja 1999 r., UZP/ZO/0-253/99, ZPO 2000, nr 1, poz. 53; wyrok Zespołu Arbitrów z dnia 17 listopada 1999 r., UZP/ZO/0-1090/99, ZPO 1999, nr 2, poz. 210; wyrok Zespołu Arbitrów z dnia 8 lutego 2000 r., UZP/ZO/0-066/00, ZPO 2000, nr 2, poz. 31; wyrok SA w Warszawie z dnia 16 lutego 2000 r., I ACa 878/00, LEX nr 1681006; wyrok Zespołu Arbitrów z dnia 9 marca 2000 r., UZP/ZO/0-133/00, ZPO 2000, nr 2, poz. 41; wyrok Zespołu Arbitrów z dnia 13 czerwca 2000 r., UZP/ZO/0-516/00, ZPO 2000, nr 2, poz. 124; wyrok Zespołu Arbitrów z dnia 16 czerwca 2000 r., UZP/ZO/0-537/00, ZPO 2000, nr 2, poz. 130; wyrok Zespołu Arbitrów z dnia 23 października 2000 r., UZP/ ZO/0-1160/00, ZPO 2000, nr 3, poz. 126; wyrok Zespołu Arbitrów z dnia 23 listopada 2000 r., UZP/ZO/0-1350/00, ZPO 2000, nr 3, poz. 159; wyrok Zespołu Arbitrów z dnia 27 listopada 2000 r., UZP/ZO/0-1361/00, ZPO 2000, nr 3, poz. 164.

20 Cf. np. wyrok SN z dnia 13 grudnia 1999 r., III CKN 478/98, OSNC 2000, nr 6, poz. 118; R. Szostak, Glosa do wyroku SN z dnia 13 grudnia 1999 r., III CKN 478/98, „Samorząd Terytorialny" 2001, nr 6, s. 68-71; J. Jerzykowski, Glosa do wyroku SN z dnia 13 grudnia 1999 r., III CKN 478/98, „Monitor Prawniczy”2001, nr 15, s. 797.

21 Cf. np. K. Muchowska-Zwara, Prawne problemy funkcjonowania konsorcjów uczestniczacych w obrocie regulowanym przez Prawo zamówień publicznych, Warszawa 2015; A. Chrząszcz, op. cit., s. 41-47; S. Babiarz, Prawo zamówień publicznych. Komentarz, Warszawa 2013, s. 215224, 722-724; E.A. Norek, Prawo zamówień publicznych. Komentarz, Warszawa 2009, s. 91-93; J. Baehr, Zamawiajacy i wykonawcy, [w:] Prawo zamówień publicznych. Komentarz, red. T. Czajkowski, Warszawa 2007, s. 128-131; E. Zielińska, Wspólna realizacja zamówienia publicznegozagadnienia wybrane, „Prawo Zamówień Publicznych” 2015, nr 1, s. 133-145; J. Lic, Konsorcjum w zamówieniach publicznych, „Prawo Zamówień Publicznych”2008, nr 4, s. 98-114; K. Gałczyńska-Lisik, Konsorcjum w świetle prawa zamówień publicznych, „Przegląd Prawa Handlowego” 2006, nr 10, s. 44-45; R. Świstak, Konsorcjum w świetle prawa zamówień publicznych-polemika, „Przegląd Prawa Handlowego” 2007, nr 3, s. 40-42; T. Kocowski, Wspólni zamawiający oraz wspólni wykonawcy w systemie zamówień publicznych, [w:] Zamórwienia publiczne - stan obecny i perspektywy, red. T. Kocowski, J. Kaspryszyn, Wrocław 2012, s. 74-90; Z. Raczkiewicz, Konsorcja w ramach zamówień publicznych, „Prawo Zamówień Publicznych” 2009, nr 2, s. 62-68.

22 K. Horubski, T. Kocowski, Konsorcjum jako instrument wsparcia matych i srednich przedsiębiorców w systemie zamówień publicznych, [w:] Nowe podejście do zamówień publicznych - zamówienia publiczne jako instrument zwiększania innowacyjności gospodarki i zrównoważonego rozwoju. Do- 
przede wszystkim do sumowania potencjałów konsorcjantów i spełnienia warunków podmiotowych udziału stawianych przez zamawiających w postępowaniu zamówieniowym. Polska regulacja wciąż pozostaje bardzo lakoniczna i ogranicza się do dwóch artykułów: art. 23 i art. 141 p.z.p. Istotniejszych zmian dotyczących udziału konsorcjum $\mathrm{w}$ postępowaniu zamówieniowym nie przyniosła najnowsza nowelizacja ustawy zamówieniowej, która weszła w życie 28 lipca 2016 r. ${ }^{23}$, choć niewątpliwie pewną doniosłość będą miały nowe rozwiązania dotyczące spełniania warunków przez konsorcja. Ustawa nowelizująca wdraża do polskiego systemu prawnego trzy dyrektywy zamówieniowe wydane w 2014 r. ${ }^{24}$, reformujące unijny system zamówień publicznych.

Ustawa nie posługuje się wprost pojęciem „konsorcjum”. W pierwszej kolejności należy przytoczyć treść art. 23 p.z.p. Zgodnie z nim wykonawcy mogą wspólnie ubiegać się o udzielenie zamówienia (ust. 1). Wymaga się od nich ustanowienia pełnomocnika do reprezentowania w postępowaniu o udzielenie zamówienia, przy czym może on ponadto zostać umocowany do zawarcia umowy w sprawie zamówienia publicznego (ust. $2)^{25}$. Przepisy dotyczące wykonawcy stosuje się odpowiednio do wykonawców wspólnie ubiegających się o udzielenie zamówienia (ust. 3). Jeżeli wybrano ofertę wykonawców występujących wspólnie, to zamawiający może żądać przed zawarciem umowy w sprawie zamówienia publicznego udostępnienia umowy regulującej współpracę wykonawców (ust. 4). Zamawiający może określić szczególny, obiektywnie uzasadniony sposób spełniania przez takich wykonawców warunków udziału w postępowaniu, jeżeli jest to uzasadnione charakterem zamówienia i proporcjonalne (nowo dodany ust. 5). Ponadto zamawiający może określić warunki realizacji zamówienia przez takich wykonawców w inny sposób niż w przypadku pojedynczych wykonawców, jeżeli jest to uzasadnione charakterem zamówienia i proporcjonalne (nowo dodany ust. 6). Specyfika podmiotów zbiorowych wymaga bowiem nieraz zastosowania wobec nich pewnych zasad szczególnych, np. w celu zapewnienia im równej pozycji w postępowaniu i na etapie realizacji.

świadczenia polskie i zagraniczne. Część I, red. J. Niczyporuk, J. Sadowy, M. Urbanek, Kazimierz Dolny 2011, s. 45-58.

23 Ustawa z dnia 22 czerwca 2016 r. o zmianie ustawy - Prawo zamówień publicznych oraz niektórych innych ustaw, Dz.U. 2016 poz. 1020.

24 Dyrektywa Parlamentu Europejskiego i Rady 2014/24/UE z 26.02.2014 r. w sprawie zamówień publicznych, uchylająca dyrektywę 2004/18/WE (Dz.Urz. UE L nr 94, s. 65), dalej dyrektywa 2014/24/UE lub dyrektywa klasyczna; dyrektywa Parlamentu Europejskiego i Rady 2014/23/ UE z 26.02.2014 r. w sprawie udzielania koncesji (Dz.Urz. UE L nr 94, s. 1), dalej dyrektywa 2014/23/UE lub dyrektywa koncesyjna; dyrektywa Parlamentu Europejskiego i Rady 2014/25/ UE z 26.02.2014 r. w sprawie udzielania zamówień przez podmioty działające w sektorach gospodarki wodnej, energetyki, transportu i usług pocztowych, uchylająca dyrektywę 2004/17/ WE (Dz.Urz. UE L nr 94, s. 243), dalej dyrektywa 2014/25/UE lub dyrektywa sektorowa.

25 I. Kołaczyńska-Wyszogrodzka, Petnomocnictwo a wspólne ubieganie się o udzielenie zamówienia publicznego, „Finanse Komunalne” 2007, nr 1, s. 93-96. 
Nowelizacja wprowadziła pewne zmiany w zakresie nazewnictwa odnośnie do warunków udziału w postępowaniu, choć merytorycznie katalog warunków pozostał w zasadzie taki sam. Mianowicie określenie „zdolność techniczna lub zawodowa” (art. 22 ust. 1b pkt 3 p.z.p.) zastępuje dotychczasowy warunek wiedzy i doświadczenia (dotychczas art. 22 ust. 1 pkt 2 p.z.p.) oraz warunek dysponowania potencjałem technicznym i osobami zdolnymi do wykonania zamówienia (dotychczas art. 22 ust. 1 pkt 3 p.z.p.). Co znaczące, w zakresie warunku „sytuacji ekonomicznej i finansowej” zamawiający może zażądać w szczególności posiadania określonego minimalnego rocznego przychodu, w tym określonego w obszarze objętym zamówieniem publicznym. Dla potwierdzenia spełnienia warunków udziału w postępowaniu, kryteriów selekcji ${ }^{26}$ i braku podstaw wykluczenia każdy z konsorcjantów składa odrębny jednolity europejski dokument zamówienia (JEDZ) lub odpowiednie oświadczenie w odpowiednim zakresie (art. 25a ust. 6 p.z.p.).

Natomiast zgodnie z art. 141 p.z.p. wykonawcy wspólnie ubiegający się o udzielenie zamówienia ponoszą solidarną odpowiedzialność za wykonanie umowy i wniesienie zabezpieczenia należytego wykonania umowy. Przepis ten ma charakter bezwzględnie wiążący. Przesądza jednak wyłącznie o solidarności biernej konsorcjantów ubiegających się o zamówienie, nie powoduje zaś skutków w postaci solidarności czynnej. Ponadto odpowiedzialność solidarna nie obejmuje wniesienia wadium ${ }^{27}$. Ponoszenie odpowiedzialności za uchybienia innych konsorcjantów z jednej strony zmniejsza atrakcyjność tej formy kooperacji przy realizacji zamówienia, z drugiej - pozwala na późniejsze powoływanie się przez każdego z konsorcjantów na wiedzę i doświadczenie wynikające $z$ całego przedsięwzięcia niezależnie od rzeczywistego zakresu prac. Przykładowo, w wyroku z dnia 25 czerwca 2009 r. Sąd Okręgowy w Poznaniu uznał, że powołanie się na doświadczanie zdobyte przy dostawie tramwajów realizowanej przez konsorcjum, w którym wykonawca pełnił jedynie funkcję logisty i dostawcy komponentów, jest wy-

26 „Kryteria selekcji” to nowe pojęcie ustawowe oznaczające obiektywne i niedyskryminacyjne kryteria ustalane w przypadku trybu przetargu ograniczonego, negocjacji z ogłoszeniem, dialogu konkurencyjnego lub ustanowienia partnerstwa innowacyjnego stosowane przy prekwalifikacji wykonawców.

27 Szerzej o odpowiedzialności konsorcjantów: A. Mucha, Odpowiedzialność uczestników konsorcjum, „Internetowy Przegląd Prawniczy TBSP UJ” 2013, nr 13, s. 43-57; M. Kalina-Nowaczyk, Solidarna odpowiedzialność wykonawców za niewykonanie lub nienależyte wykonanie zamówienia publicznego, [w:] Odpowiedzialność cywilnoprawna wobrocie gospodarczym, red. A. Śmieja, Wrocław 2011, s. 106-118; E. Kowalewski, W. Mogilski, Gwarancja ubezpieczeniowa członka konsorcjum jako wadium w postępowaniu o uzyskanie przez konsorcjum zamówienia publicznego, „Wiadomości Ubezpieczeniowe” 2014, nr 1, s. 23-31; J. Pokrzywniak, Gwarancja na gruncie PZP, „Miesięcznik Ubezpieczeniowy” 2014, nr 9, s. 39-40; M. Makowski, Gwarancja bankowa jako forma wniesienia wadium - kontrowersje interpretacyjne, „Prawo Zamówień Publicznych” 2008, nr 2, s. 22-41. 
starczające dla spełnienia w kolejnym postępowaniu warunku posiadania doświadczenia w zakresie dostaw tramwajów ${ }^{28}$.

Warto zauważyć, że w odrzuconym przez Radę Ministrów projekcie nowego Prawa zamówień publicznych z października $2015 \mathrm{r} .{ }^{29}$ proponowano rezygnację z obligatoryjnej solidarnej odpowiedzialności konsorcjantów. W przyjętej nowelizacji treść art. 141 p.z.p. pozostawiono jednak bez zmian.

Obecnie dominuje trafny pogląd, że istotą wspólnego ubiegania się o udzielenie zamówienia publicznego przez konsorcjantów jest połączenie doświadczeń, wiedzy, potencjału technicznego, osobowego, ekonomicznego i finansowego poszczególnych uczestników konsorcjum, którzy nie są w stanie samodzielnie spełnić wymogów przedstawionych przez zamawiającego. Spełnienie przez nich warunków z art. 22 ust. 1b p.z.p. należy więc - w dużym uproszczeniu - co do zasady oceniać łącznie, z pewnymi wyjątkami, np. w zakresie warunku posiadania kompetencji lub uprawnień. Natomiast każdy z wykonawców wspólnie ubiegających się o zamówienie musi spełnić oddzielnie warunki niepodlegania wykluczeniu z postępowania zawarte w art. 24 ust. 1 i 5 p.z.p. ${ }^{30}$

Dopuszczalność zmian i przekształceń podmiotowych - ze względu na brak regulacji - była źródłem szczególnych kontrowersji, przy czym zarówno na etapie postępowania, jak i na etapie wykonawczym zmiany podmiotowe uznawano raczej za niedopuszczalne ${ }^{31}$. Natomiast w znowelizowanym art. 144 ust. 1 pkt 4 p.z.p. wprowadzono możliwość zmiany podmiotowej w zawartej umowie (umowie ramowej) w stosunku do treści oferty $\mathrm{w}$ następujących trzech sytuacjach: 1) zmiana podmiotowa została przewidziana przez zamawiającego we wzorze umowy, 2) zmiana następuje w wyniku połączenia, podziału, przekształcenia, upadłości, restrukturyzacji lub nabycia dotychczasowego wykonawcy lub jego przedsiębiorstwa, o ile nowy wykonawca spełnia warunki udziału w postępowaniu, nie zachodzą wobec niego podstawy wykluczenia oraz nie pociąga to za sobą innych istotnych zmian umowy, 3) w wyniku przejęcia przez zamawiającego zobowiązań wykonawcy względem jego podwykonawców.

Warto zasygnalizować, że wspólne ubieganie się o udzielenie zamówienia publicznego przez konsorcjum może ułatwiać tworzenie tzw. zmów przetargowych, czyli - w myśl

28 Wyrok SO w Poznaniu z dnia 25 czerwca 2009 r., X Ga 198/09, www.uzp.gov.pl.

29 Projekt z dnia 12 października 2015 r., https://legislacja.rcl.gov.pl/docs//2/12271652/12285001/ 12285002/ dokument188464.pdf [dostęp: 1.06.2015].

30 K. Horubski, T. Kocowski, Spetnianie warunków udziatu w postępowaniu przez wykonawców wspólnie ubiegajacych się o zamówienie, „Prawo Zamówień Publicznych” 2014, nr 1, s. 40-60; M. Grabarczyk, Dostateczna wiedza i doświadczenie jako warunek ubiegania się o zamówienie publiczne, „Prawo Zamówień Publicznych” 2014, nr 1, s. 61-74; J. Wiak, Spetnienie warunków udziatu w postępowaniu przez wykonawców wspólnie ubiegających się o udzielenie zamówienia publicznego, „Finanse Komunalne” 2012, nr 6, s. 5-19.

$31 \mathrm{~K}$. Horubski, Zmiany sktadu konsorcjum w postępowaniu o udzielenie zamówienia oraz na etapie wykonywania zamówienia, Wrocław 2012, s. 24-37. 
art. 6 ust. 1 pkt 7 ustawy z 16 lutego 2007 r. o ochronie konkurencji i konsumentów ${ }^{32}$ porozumień, których celem lub skutkiem jest wyeliminowanie, ograniczenie lub naruszenie w inny sposób konkurencji na rynku właściwym, polegające na uzgadnianiu przez przedsiębiorców i przedsiębiorcę będącego organizatorem przetargu warunków składanych ofert, w szczególności zakresu prac lub ceny ${ }^{33}$. W jednej z decyzji prezes UOKiK uznał zawarcie umowy konsorcjalnej na potrzeby złożenia wspólnej oferty przetargowej przez przedsiębiorców, którzy mogliby przedstawić oferty w przetargu samodzielne za zmowę przetargową ${ }^{34}$.

\section{Konsorcjum w brytyjskim prawie zamówień publicznych}

\section{Konsorcjum w ogólności}

Zarówno pojęcie konsorcjum, jak i pojęcie joint venture nie mają w prawie brytyjskim swojej definicji legalnej. To drugie pojęcie przeważnie bywa używane dla określenia różnego rodzaju porozumień, gdzie dwie albo więcej stron współpracują w prowadzeniu działalności gospodarczej. Przejawia się to np. we wspólnym podziale zysku, wniesieniu środków pieniężnych, rzeczy, wiedzy czy zdolności do wspólnego przedsięwzięcia ${ }^{35}$.

$\mathrm{Z}$ powodu braku przepisów prawnych regulujących szczegółowo konsorcjum czy joint venture relacje pomiędzy stronami uczestniczącymi w tego rodzaju porozumieniu - przy wyborze konstrukcji joint venture jako umowy kooperacyjnej (collaboration agreement) lub partnership - poddane są sądowemu prawu precedensowemu (common law), przepisom prawa o spółkach osobowych (partnership law), prawu podatkowemu, prawu konkurencji (unijnemu i krajowemu) oraz innym przepisom regulującym kwestie szczegółowe (np. własność intelektualna, zatrudnienie, obrót nieruchomościami). Umowa konsorcjalna, podobnie jak umowa spółki zwykłej (partnership), nie kreuje odrębnego podmiotu ${ }^{36}$.

Proces tworzenia konsorcjum jest znacznie prostszy niż procedura rejestracji spółek kapitałowych. Nie istnieją wymogi konsultacyjne z żadnym organem publicznym (np. organem ochrony konkurencji) ani formalna procedura co do zakładania i rozwiązywania konsorcjum. Powstanie stosunku konsorcjalnego wymaga jedynie zgody stron na związanie się umową konsorcjalną regulującą prawa i obowiązki w ramach wspólnego przedsięwzięcia. Umowa nie wymaga szczególnej formy ani żadnej formy uwierzytelnienia (np. notarialnego) czy wpisu do rejestru publicznego. W praktyce zaleca się jednak stronom sporządzenie umowy w formie pisemnej w celu uniknięcia nieporozumień

32 Ustawa z dnia 16 lutego 2007 r. o ochronie konkurencji i konsumentów, t.j. Dz.U. 2015 poz. 184 ze zm.

33 J. Wiak, op. cit., s. 6.

34 Decyzja prezesa UOKiK z dnia 31 grudnia 2012 r., RLU-38/2012.

35 S. Williams-Elegbe, Fighting Corruption in Public Procurement. A Comparative Analysis of Disqualification or Debarment Measures, Oxford 2012, s. 200.

36 C. Newsholme, P. Groves, Joint ventures in the UK: overview, Practical Law/el. 2015. 
czy przedwczesnego rozwiązania umowy. Nie ma również żadnych ograniczeń w prawie kontraktowym co do celu (przedmiotu) umowy konsorcjalnej, pod warunkiem że prowadzona działalność jest legalna. Stąd konsorcjum może zostać zawiązane w każdym celu prawnie dozwolonym ${ }^{37}$.

Jeśli chodzi o czas, na jaki zawierana jest umowa konsorcjum, to może być ona zawarta również na czas nieokreślony. Jest wówczas rozwiązywalna zgodnie z regułami określonymi w umowie. Konsorcjanci zazwyczaj postanawiają, że wspólne przedsięwzięcie automatycznie rozwiąże się w razie likwidacji lub upadłości któregoś z konsorcjantów. Odnośnie do liczby konsorcjantów, również nie przewiduje się żadnych ograniczeń. Natomiast możliwe jest określenie w umowie zakresu uprawnień do ekonomicznych korzyści i ponoszonej odpowiedzialności i ryzyka w sposób niejednakowy dla wszystkich konsorcjantów. Strony mogą też swobodnie wybrać prawo właściwe dla umowy konsorcjum oraz uzgodnić klauzulę prorogacyjną. Nie istnieją także żadne ograniczenia czy konieczność uzyskiwania zezwolenia na uczestnictwo w konsorcjum podmiotu zagranicznego ${ }^{38}$. Ze względu na brak ustawowej regulacji oraz zasadę parol evidence rule (zgodnie $\mathrm{z}$ którą sądy angielskie nie dopuszczają dowodów na okoliczności towarzyszące redagowaniu umowy w celu wykazania, że rzeczywista intencja stron umowy była inna, niż to wynika $z$ treści samej umowy ${ }^{39}$ ) brytyjskie umowy konsorcjalne są bardzo rozbudowane.

Odpowiedzialność konsorcjantów względem kontrahenta zewnętrznego z tytułu umowy może być łączna (joint), indywidualna (several) lub solidarna (joint and several) w zależności od treści stosunku umownego z kontrahentem. Pierwszy rodzaj odpowiedzialności jest typowy dla umów zawieranych z joint venture ${ }^{40}$, zatem każdy uczestnik joint venture będzie odpowiadał za całość zobowiązania. Przy odpowiedzialności indywidualnej każdy konsorcjant odpowiadałby jedynie za swoją część. Odpowiedzialność solidarna w prawie brytyjskim przypomina polską instytucję solidarnej odpowiedzialności, zatem kontrahent mógłby żądać wykonania zobowiązania w całości lub w części od wszystkich konsorcjantów łącznie, od kilku z nich lub od każdego z osobna. Takie rozwiązanie należałoby jednak wprost przewidzieć w umowie ${ }^{41}$.

Umowa konsorcjalna - przy odpowiednim rozmiarze działalności - może podlegać rygorom unijnego prawa konkurencji, jeśli mogłaby mieć bezpośredni lub pośredni istotny wpływ na obrót pomiędzy państwami członkowskimi UE. Analogicznie w pewnych okolicznościach konsorcjum podlega brytyjskiemu prawu konkurencji, w tym ustawie

37 Ibidem.

38 Ibidem.

39 E. Myrczek, The art of drafting contracts - o podobienstwach i różnicach polskich umów i angielskich kontraktów, „Edukacja Prawnicza” 2008, nr 2, s. 3.

40 Np. Townsend v. Stone Toms E Partners (1981), "Weekly Law Reports"1981, t. 1, s. 1153-1160.

41 J. Bailey, Construction Law, Abingdon 2011, s. 1062-1063. 
Competition Act z 1998 r. ${ }^{42}$, która zakazuje nadużywania pozycji dominującej i stosowania pewnych antykonkurencyjnych porozumień skutkujących wyeliminowaniem, ingerencją lub zakłócaniem konkurencji, w tym na rynku krajowym. Stąd strony przed wdrożeniem umowy konsorcjalnej powinny same ocenić, czy konsorcjum nie narusza unijnych i brytyjskich norm prawa konkurencji. W szczególności strony muszą ocenić, czy postanowienia zawarte w umowie konsorcjalnej nie mają charakteru antykonkurencyjnych klauzul ograniczających konkurencję, przy czym ocena ta zależy od charakteru klauzuli antykonkurencyjnej. Umowa między rzeczywistymi lub potencjalnymi konkurentami (przed utworzeniem konsorcjum) może być zakwalifikowana jako niedozwolone horyzontalne porozumienie o podziale rynku ograniczające konkurencję. Wykryte przez regulatora może zaś skutkować sankcjami. Niemniej - wyjątkowo - utworzenie konsorcjum byłoby dopuszczalne w celu złożenia oferty na skomplikowany projekt, gdy żadna ze stron nie ma odpowiednich zasobów, żeby zrealizować przedsięwzięcie samodzielnie. $Z$ kolei tzw. wertykalne porozumienia (zawierane między podmiotami na różnych szczeblach obrotu) są dopuszczalne, jeśli udział we właściwym rynku każdej ze stron wynosi poniżej 30\% i jeśli brak konkurencji między stronami będzie trwał nie dłużej niż 5 lat ${ }^{43}$.

\section{Spółka cywilna}

W prawie brytyjskim nie istnieje podział na spółki prawa handlowego i spółki prawa cywilnego ze względu na brak formalnego rozróżnienia prawa prywatnego na prawo cywilne i handlowe. Za zbliżoną formę do spółki cywilnej można uznać spółkę zwykła (private partnership) unormowaną w ustawie Partnership Act z 1890 r. ${ }^{44}$ uzupełnionej ustawą Limited Partnerships Act z 1907 r. ${ }^{45}$ Forma ta łączy w sobie elementy odpowiadające polskiej spółce cywilnej i jawnej i jest ustanawiana na podstawie umowy ustnej lub pisemnej zawartej pomiędzy co najmniej dwoma podmiotami chcącymi prowadzić wspólnie interes. Co istotne, interes ten nie musi mieć charakteru stałego i może polegać na podjęciu jednorazowego wspólnego przedsięwzięcia. Umową spółki zwykłej wspólnicy nie kreują osoby prawnej. Powstaje jednak zazwyczaj wyodrębniony niepodzielny majątek spółki, choć wspólnicy mogą z tego rozwiązania zrezygnować. Sama zaś spółka wyposażona zostaje w bierną i czynną legitymację procesową, a także podmiotowość na

42 Competition Act 1998, http://www.legislation.gov.uk/ukpga/1998/41/pdfs/ukpga_19980041_ en.pdf [dostęp: 30.06.2016].

43 C. Newsholme, P. Groves, op. cit.

44 Partnership Act 1890, http://www.legislation.gov.uk/ukpga/1890/39/pdfs/ukpga_18900039_ en.pdf [dostęp: 30.06.2016].

45 Limited Partnerships Act 1907, http://www.legislation.gov.uk/ukpga/1907/24/pdfs/ukpga_19 070024_en.pdf [dostęp: 30.06.2016]. 
gruncie prawa pracy i prawa podatkowego. Za zobowiązania związane z działalnością spółki odpowiada spółka całym swoim majątkiem oraz solidarnie wspólnicy spółki ${ }^{46}$.

Nie istnieje normatywna procedura wymagana dla utworzenia spółki zwykłej, wymaga się jedynie, aby strony umowy zamierzały prowadzić działalność wspólnie z nastawieniem na zysk. W związku z tym istnieje ryzyko uznania umowy konsorcjalnej za tzw. dorozumianą spółkę zwykłą (de facto partnership), jeśli powstały stosunek prawny spełnia wymogi ustawowe przewidziane dla takiej spółki. Skutkuje to przyjęciem przez strony umowy odpowiedzialności za działania pozostałych uczestników struktury, bowiem wspólnicy ponoszą solidarną i niegraniczoną odpowiedzialność za działania podejmowane w ramach spółki. Dlatego też strony zazwyczaj starają się zawrzeć w umowie konsorcjalnej wyraźne postanowienie, że umowa nie będzie interpretowana jako umowa spółki $^{47}$.

\section{Ramy prawne zamówień publicznych}

W Anglii, Walii i Irlandii Północnej istnieją obecnie trzy główne akty prawne dotyczące udzielania zamówień publicznych, przy czym oddzielne (chociaż podobne) uregulowania istnieją w Szkocji (w opracowaniu pominięte zostanie jednak prawo szkockie).

Pierwszym aktem są Przepisy w sprawie zamówień publicznych z 2015 r. (Public Contracts Regulations $2015^{48}$ ) wdrażające unijne reguły zawarte w dyrektywie klasycznej z 2014 r., a więc reguły odnoszące się do zamówień na usługi, dostawy i roboty budowlane udzielanych przez zamawiających innych niż zamawiający sektorowi. Zostały one uchwalone przez brytyjski Parlament w dniu 5 lutego 2015 r. i weszły w życie 26 lutego 2015 r., zastępując Przepisy w sprawie zamówień publicznych z 2006 r. (Public Contracts Regulations $2006^{49}$ ). Drugim aktem prawnym są uchwalone 17 marca 2016 r. Przepisy w sprawie zamówień sektorowych (Utilities Contracts Regulations 2016 ${ }^{50}$ ) wdrażające unijne reguły dotyczące zamówień na usługi, dostawy i roboty budowlane udzielanych przez zamawiających sektorowych. Zastąpiły one z dniem 18 kwietnia 2016 r. Przepisy w sprawie zamówień sektorowych z 2006 r. (Utilities Contracts Regulations 2006 ${ }^{51}$ ). Trzeci akt to natomiast uchwalone 17 marca 2016 r. Przepisy w sprawie koncesji (Con-

46 I. Hasińska, Charakter prawny spótki cywilnej na tle historycznym i prawnoporównawczym [praca doktorska], Wydział Prawa i Administracji Uniwersytetu im. Adama Mickiewicza w Poznaniu, 2013, s. 99-108.

47 C. Newsholme, P. Groves, op. cit.

48 Statutory Instrument 2015 No. 102. The Public Contracts Regulations 2015, http://www.legislation.gov.uk/uksi/2015/102/pdfs/uksi_20150102_en.pdf [dostęp: 30.06.2016], dalej p.c.r.

49 Statutory Instrument 2006 No. 5. The Public Contracts Regulations 2006, http://www.legislation.gov.uk/uksi/2006/5/pdfs/uksi_20060005_en.pdf [dostęp: 30.06.2016].

50 Statutory Instrument 2016 No. 274. The Utilities Contracts Regulations 2016, http://www. legislation.gov.uk/ uksi/2016/274/pdfs/uksi_20160274_en.pdf [dostęp: 30.06.2016].

51 Statutory Instrument 2006 No. 6. The Utilities Contracts Regulations 2006, http://www.legislation.gov.uk/uksi/2006/6/pdfs/uksi_20060006_en.pdf [dostęp: 30.06.2016]. 
cessions Contracts Regulations 2016 ${ }^{52}$ ), które weszły w życie 18 kwietnia 2016 r. i wdrażają dyrektywę koncesyjną. Wskazywane akty prawne są jednocześnie implementacją dyrektywy odwoławczej ${ }^{53}$, przy czym zamówienia publiczne w Anglii i Walii objęte są kognicją High Court of Justice.

Prawodawca brytyjski stosuje technikę redakcyjną wdrażania dyrektyw unijnych polegającą na dosłownym przeniesieniu treści dyrektyw do treści przepisów krajowych tak dalece, jak to w danym przypadku jest możliwe. Stąd przy analizie przepisów krajowych celowe będzie przywoływanie podobnie sformułowanych przepisów dyrektywy klasycznej. Należy zauważyć, że mimo istotnej reformy systemu zamówień publicznych w Wielkiej Brytanii w 2015 i 2016 r. przepisy dotyczące grup wykonawców nie zmieniły się znacząco.

\section{Regulacja udziału konsorcjum w postępowaniu zamówieniowym}

Konsorcjum składające wspólną ofertę i wykonujące zamówienie publiczne bywa w literaturze określane jako project joint venture. Konsorcja takie zasadniczo można podzielić na dwa typy: konsorcja zintegrowane (integrated joint ventures) i niezintegrowane (non-integrated joint ventures). W pierwszym modelu konsorcjum stanowi centrum zysków, a konsorcjanci przyjmują solidarną odpowiedzialność wobec kontrahenta i partycypują w stosunku wewnętrznym w stratach i zobowiązaniach w uzgodnionej proporcji. Prace mogą być wykonywane centralnie na zasadzie poolu przez konsorcjantów lub poprzez zaangażowanych podwykonawców. W drugim modelu prace dzielone są na odrębne segmenty, które każdy konsorcjant wykonuje na własny koszt i odpowiada w stosunku wewnętrznym za wszelkie zobowiązania wynikające $z$ tego segmentu. Konsorcjum nie stanowi wówczas centrum zysków ${ }^{54}$. Rozwiązania te przypominają finansowe i zadaniowe modele rozliczeń konsorcjum występujące w Polsce.

S. Arrowsmith wskazuje, że stosunkowo często przy skomplikowanych zamówieniach udzielanych przez brytyjskie instytucje zamawiające wykonawcy (zwłaszcza prowadzący działalność w różnych dziedzinach) zrzeszają się i uczestniczą w konsorcjach. Podaje przykład zamówienia na wybudowanie i zarządzanie więzieniem, gdzie spółka z branży budowlanej może kooperować ze spółkami z branży zarządzania i branży ochroniarskiej w celu przedłożenia oferty ${ }^{55}$. Powodem tworzenia konsorcjów przetargowych, podobnie jak w Polsce, bywa, po pierwsze, konieczność spełnienia wymagań określonych przez

52 Statutory Instrument 2016 No. 273 The Concession Contracts Regulations 2016, http://www. legislation.gov.uk/ uksi/2016/273/pdfs/uksi_20160273_en.pdf [dostęp: 30.06.2016].

53 Dyrektywa Parlamentu Europejskiego i Rady 2007/66/WE z dnia 11 grudnia 2007 r. zmieniająca dyrektywy Rady 89/665/EWG i 92/13/EWG w zakresie poprawy skuteczności procedur odwoławczych w dziedzinie udzielania zamówień publicznych, Dz.Urz. UE L nr 335, s. 31.

54 I. Hewitt, Joint Ventures, London 2001, s. 63.

55 S. Arrowsmith, The Law of Public and Utilities Procurement. Regulation in the EU and UK, London 2014, s. 1321. 
zamawiającego i przekraczających możliwości jednego wykonawcy, np. odnośnie do uzyskania gwarancji bankowych, zdolności do wykonania zamówienia (np. odpowiednio szeroka sieć punktów obsługowych), posiadania certyfikatów jakości czy odpowiedniej sytuacji finansowej. Po drugie, spółka będąca w stanie samodzielnie uczestniczyć $\mathrm{w}$ postępowaniu zamówieniowym może utworzyć grupę $\mathrm{z}$ innymi wykonawcami w celu wsparcia własnej oferty, np. wzmocnienia zasobów czy kompetencji i wiedzy w danej dziedzinie. Podmioty wspólnie uczestniczące w postępowaniu są traktowane jak jeden uczestnik. O ile dozwolone są konsorcja przetargowe zawiązywane w dobrej wierze, o tyle zmowy przetargowe mogące powodować zakłócenia na rynku są zabronione i mogą być podważane w trybie właściwych postępowań ${ }^{56}$.

Podczas gdy w poprzednich przepisach z 2006 r. posługiwano się pojęciem „konsorcjum” posiadającym swoją definicję legalną, nowe przepisy używają terminu "grupa wykonawców”. W związku ze zmianą definicji „wykonawcy” uwzględniającej również grupy wykonawców, nie powtórzono odpowiednika art. 28 § z 2006 r., zgodnie z którym jakiekolwiek odniesienie do wykonawcy, dostawcy lub usługodawcy obejmowało odniesienie do każdego indywidualnego członka konsorcjum, oraz art. 28 § 1, który definiował konsorcjum jako dwa lub więcej podmiotów, z których przynajmniej jeden jest wykonawcą, działających wspólnie w celu zdobycia zamówienia publicznego ${ }^{57}$.

Aktualnie w art. 19 § 3-6 p.c.r. wciąż przewiduje się, że grupy wykonawców ${ }^{58}$, w tym tymczasowe stowarzyszenia, mogą uczestniczyć w postępowaniu zamówieniowym, a zamawiający nie może od nich wymagać przyjęcia określonej formy prawnej w celu złożenia oferty lub wniosku o udział w postępowaniu. Przepis art. 19 ust. 2 dyrektywy klasycznej stanowi, że instytucje zamawiające nie mogą wymagać, aby grupy wykonawców przybierały określoną formę prawną podczas składania oferty lub wysuwania swojej kandydatury. Oznacza to, że zamawiającym wyraźnie zabroniono odrzucania oferty na tej podstawie, że została ona przedłożona przez konsorcjum złożone $z$ więcej niż jednego podmiotu prawnego zamiast pojedynczego podmiotu. Przepis ten wdrożono w Wielkiej Brytanii w art. 19 § 3 p.c.r. (poprzednio art. 28 §). Jest to przypuszczalnie potwierdzenie jednego $\mathrm{z}$ aspektów bardziej ogólnej zasady wywodzonej z orzecznictwa TFUE, która zakazuje ograniczeń dotyczących uczestniczenia w rynkach, bazujących na formie prawnej lub składzie wykonawców, gdy te ograniczenia są nieuzasadnione ${ }^{59}$.

$\mathrm{Z}$ drugiej strony, żeby zabezpieczyć interesy instytucji zamawiającej w zapewnieniu prostego systemu odpowiedzialności i egzekwowania prawnych zobowiązań, wprost za-

56 G.L. Albano, G. Spagnolo, M. Zanza, Regulating Joint Bidding in Public Procurement, „Journal of Competition Law and Economics" 2009, t. 5, nr 2, s. 339.

57 S. Arrowsmith, op.cit., s. 1320.

58 Odwołanie do grup jest odniesieniem do jakichkolwiek grup wykonawców, które składają oferty lub wysuwają swoje kandydatury wspólnie, nie tylko w formie konsorcjum, ale również z zastosowaniem innych modeli kooperacji.

59 S. Arrowsmith, op.cit., s. 1321. 
strzeżono w art. 19 ust. 3 dyrektywy klasycznej i w art. 19 § 6 p.c.r. (poprzednio art. 28 § 3), że zamawiający może wymagać, aby konsorcjum utworzyło określony podmiot prawny, zanim dojdzie do zawarcia umowy o zamówienie publiczne, w zakresie, w jakim taka zmiana jest niezbędna do zadowalającej realizacji zamówienia. Komentowany przepis stanowi, iż instytucje zamawiające mogą wymagać od grup wykonawców, aby przyjęły określoną formę prawną w momencie udzielenia zamówienia, w zakresie, w jakim taka zmiana jest konieczna dla zadowalającego wykonania zamówienia. Stąd podczas fazy wykonywania zamówienia zamawiający miałby możliwość utrzymywania stosunków z jednym tylko podmiotem, a nie z grupą wykonawców ${ }^{60}$.

Reguły zakazujące żądania od grupy wykonawców uczestniczących wspólnie przyjęcia określonej formy prawnej w momencie składania oferty lub wniosku o udział w postępowaniu, ale pozwalające żądać utworzenia podmiotu prawnego dla wykonania zamówienia, gdy jest to konieczne, zostały zawarte odpowiednio w art. 19 ust. 2 i 3 nowej dyrektywy klasycznej. Pierwszy z tych przepisów precyzuje ponadto rozwiązanie (które zdaje się było dopuszczalne również pod rządami dyrektywy 2004/18/WE ${ }^{61}$ ), iż w razie potrzeby i pod warunkiem, że jest to obiektywnie uzasadnione i proporcjonalne, instytucje zamawiające mogą sprecyzować sposób, w jaki grupy wykonawców mają spełnić wymogi dotyczące sytuacji ekonomicznej i finansowej lub zdolności technicznej i zawodowej. Przepis precyzuje, że powinno to zostać dokonane w dokumentach zamówienia. Art. 19 ust. 2 dyrektywy klasycznej stanowi również, że warunki realizacji zamówienia przez takie grupy wykonawców, odmienne od warunków nakładanych na pojedynczych uczestników, muszą być obiektywnie uzasadnione i proporcjonalne. I znowu, przepis ten zasadniczo wprost wyraża stanowisko przyjmowane już pod rządami dyrektywy 2004/18/WE ${ }^{62}$. Rozwiązanie to wdrożono w art. 19 § 4 p.c.r., który stanowi, że gdy jest to konieczne, instytucja zamawiająca może sprecyzować w dokumentacji zamówieniowej, w jaki sposób grupy wykonawców mają spełnić wymogi odnoszące się do kondycji ekonomicznej i finansowej, zdolności technicznych i zawodowych, pod warunkiem że jest to obiektywnie uzasadnione i proporcjonalne.

Brytyjskie przepisy (podobnie jak dyrektywa klasyczna) nie zawierają wyraźnych reguł co do ewentualnego obowiązku albo uprawnienia po stronie zamawiającego odnośnie do wykluczenia konsorcjum w razie zmiany podmiotowej. Przewidziano jednak w nowym art. 72 § 1 lit. (d) p.c.r. możliwość zmiany podmiotowej w dwóch sytuacjach: 1) kiedy zamieszczono jednoznaczną klauzulę przeglądową w umowie o zamówienie (a wcześniej w dokumentach zamówienia) bądź 2) w razie sukcesji uniwersalnej lub częściowej nowe-

\section{Ibidem.}

61 Dyrektywa Parlamentu Europejskiego i Rady 2004/18/WE z 31.03.2004 r. w sprawie koordynacji procedur udzielania zamówień publicznych na roboty budowlane, dostawy i usługi. Dz.Urz. UE L nr 134, s. 114, dalej dyrektywa 2004/18/WE.

62 S. Arrowsmith, op.cit., s. 1322. 
go wykonawcy w miejsce pierwotnego, będącej wynikiem restrukturyzacji (np. przejęcia, fuzji, niewypłacalności), o ile nowy wykonawca spełnia podmiotowe kryteria udziału i nie pociąga to za sobą istotnych modyfikacji umownych mających na celu obejście przepisów w sprawie zamówień. Reguły te będą mieć zapewne zastosowanie również do zmian podmiotowych w konsorcjum. Już wcześniej zasadniczo przyjmowano, że zmiana podmiotowa mogła być podstawą dyskwalifikacji konsorcjum tylko wtedy, gdy była istotna, tj.gdy mogła mieć wpływ na decyzję zamawiającego, np. co do spełnienia warunków podmiotowych. Powoływano się na zasadę uczciwej konkurencji oraz konieczność zapobiegania nadużywaniu swobodnego uznania przez zamawiających ${ }^{63}$.

Jeśli jeden z konsorcjantów zostanie skazany za przestępstwa określone w art. 57 § 1 p.c.r. (np. za korupcję), należy ustalić, czy wpływa to na zdolność pozostałych konsorcjantów do ubiegania się o udzielenie zamówienia. Brytyjskie przepisy milczą w tej kwestii, ale przyjmuje się, że pozostali konsorcjanci nie mogą ubiegać się o udzielenie zamówienia tylko wtedy, gdy opierali się na zasobach, zdolnościach lub wiedzy skazanego czy też wykluczonego partnera. Jednakże konsorcjanci wciąż będą mogli ubiegać się o zamówienie, jeśli znajdą partnera, który zastąpi tego wykluczonego ${ }^{64}$.

Nie jest jasne, czy w systemie brytyjskim możliwe jest uczestniczenie w więcej niż jednym konsorcjum, przy czym z jednej strony wskazuje się na niedopuszczalność takiej praktyki ze względu na zakłócenia konkurencji i ryzyko ujawnienia informacji o ofercie, z drugiej zaś dopuszcza się pewne wyjątki, zwłaszcza w kontekście stosowania przepisów o minimalnej liczbie oferentów ${ }^{65}$.

Zgodnie z art. 63 § 6 p.c.r. (poprzednio art. 24 §) grupa wykonawców może polegać na zdolnościach uczestników grupy lub innych podmiotów. Zatem przy ocenie kwalifikacji wykonawców starających się o uczestnictwo jako konsorcjum zamawiający musi ocenić kwalifikacje konsorcjum jako całości w zakresie, w jakim zasoby są dostępne dla konsorcjum w przypadku konkretnego zamówienia ${ }^{66}$. Przepis odsyła do norm uprawniających pojedynczego wykonawcę do polegania na zasobach innych podmiotów dla wykazania swoich zdolności. W tym zakresie art. 63 ust. 1 dyrektywy klasycznej stanowi, że wykonawca może - w stosownych sytuacjach oraz w przypadku konkretnego zamówienia - polegać na zdolnościach innych podmiotów, niezależnie od charakteru prawnego łączących go z nimi powiązań. Musi on w takiej sytuacji udowodnić instytucji

63 Ibidem, s. 1323.

64 S. Williams-Elegbe, op. cit., s. 201-202.

65 S. Arrowsmith, op.cit., s. 1323.

66 Przykładowo, przy ocenie, czy istnieje odpowiednia zdolność techniczna dostępna dla wykonawców zamówienia, zamawiający musi wziąć pod uwagę wszystkie zasoby techniczne rzeczywiście bezpośrednio dostępne konsorcjum jako całości i nie może wymagać, żeby każdy członek grupy posiadał odpowiednią zdolność indywidualnie. 
zamawiającej, że będzie dysponował niezbędnymi zasobami, np. przedstawiając w tym celu stosowne zobowiązanie takich podmiotów ${ }^{67}$. Zasadniczo wykonawca może opierać się na jakichkolwiek środkach dowodowych, które są odpowiednie do wykazania, że rzeczywiście posiada on wymagane zasoby do swojej dyspozycji - zasadę tą wyrażono literalnie w art. 60 ust. 1 dyrektywy klasycznej z 2014 r. (pośrednio w art. 47 ust. 2 dyrektywy klasycznej z 2004 r.) i w art. 63 § 3 p.c.r. ${ }^{68}$

S. Arrowsmith zauważa, że wprowadzone regulacje uwzględniają i w zasadzie potwierdzają pewne zasady wynikające z orzecznictwa Trybunału Sprawiedliwości, które są przydatne przy interpretacji tych przepisów. Przywołuje przy tym sprawę C-389/92, Ballast Nedam ${ }^{69}$; C-5/97, Ballast Nedam ${ }^{70}$; C-176/98, Holst Italia ${ }^{71}$; C-218/11, Édukövízig i Hochtief Construction ${ }^{72}$. W tym miejscu należy ograniczyć się jedynie do przywołania brytyjskiej sprawy Harmon ${ }^{73}$, w której sąd wskazał, że wykonawca był uprawniony do polegania na zasobach innych podmiotów w grupie, przy założeniu, że każda ze spółek w grupie mogłyby zostać podstawiona jako główny wykonawca przed zawarciem umowy o zamówienie publiczne ${ }^{74}$.

Analizowane przepisy dyrektywy (art. 63 ust. 1-2) i prawa brytyjskiego (art. $63 \S 1$ i 6 p.c.r.) dotyczą sytuacji ekonomicznej i finansowej oraz możliwości technicznych i zawodowych. Poprzednio zarówno na poziomie unijnym, jak i krajowym kategorie te były umieszczone w odrębnych jednostkach redakcyjnych. Przepisy krajowe stanowią najpierw o ogólnej regule dopuszczającej poleganie na innych podmiotach, a następnie odnoszą się do warunku wymagania dowodu, że odpowiednie zasoby będą dla wykonawcy dostępne. Reguły dotyczące zdolności technicznych i zawodowych są więc takie same jak te stosowane w przypadku sytuacji ekonomicznej i finansowej. Inne są jednak reguły powoływania się na kwalifikacje zawodowe, wykształcenie i doświadczenie zawodowe

67 Przykładowo, spółka-córka polega na zasobach finansowych jej spółki-matki, gdy są one dostępne dla spółki-córki. Musi jednak przedstawić stosowne oświadczenie spółki-matki.

68 S. Arrowsmith, op.cit., s. 1196 i 1323.

69 Wyrok TS z dnia 14 kwietnia 1994 r. w sprawie C-389/92, Ballast Nedam Groep, ECR 1994, s. I-1289.

70 Wyrok TS z dnia 18 grudnia 1997 r. w sprawie C-5/97, Ballast Nedam Groep v. Belgia, ECR 1997, s. I-07549.

71 Wyrok TS z dnia 2 grudnia 1999 r. w sprawie C-176/98, Holst Italia SpA v. Comune di Cagliari, ECR 1999, s. I-1289.

72 Wyrok TS z dnia 18 października 2012 r. w sprawie C-218/11, Észak-dunántúli Környezetvédelmi és Vízügyi Igazgatóság (Édukövízig), Hochtief Construction AG Magyarországi Fióktelepe v. Közbeszerzések Tanácsa Közbeszerzési Döntóbizottság, ECLI EU C 2012, 643.

73 Harmon CFEM Facades (UK) Ltd v. The Corporate Officer of the House of Commons (2000) 2 L.G.L.R. 372.

74 S. Arrowsmith, op. cit., s. 1197. Prawdopodobnie nie chodziło o to, że grupa może jednostronnie nominować kogokolwiek z jej członków jako głównego wykonawcę. Rozstrzygnięcie z Harmon wydaje się raczej bazować na tym, że zamawiający wcześniej w procedurze zaakceptował podstawienie przez grupę jako głównego wykonawcę innego członka grupy. 
(art. 63 § 2 p.c.r.). Choć nie jest konieczne, żeby każda spółka w konsorcjum spełniała warunki co do kwalifikacji zawodowych i wykształcenia, niezbędne jest przedstawienie takiego wymogu podmiotowi wykonującemu w ramach projektu prace, do których potrzebne są kwalifikacje, co pozwoli je przypisać konsorcjum jako całości. Takie podejście prezentował przedtem TSUE, np. w sprawie C-399/05, Komisja v. Republika Grecji ${ }^{75}$. $\mathrm{W}$ dyrektywie klasycznej to podejście zostało wyraźnie potwierdzone w art. 63 ust. 1, który stanowi, że „w odniesieniu do kryteriów dotyczących wykształcenia i kwalifikacji zawodowych, określonych w załączniku XII część II lit. f), lub dotyczących stosownego doświadczenia zawodowego, wykonawcy moga polegać na zdolności innych podmiotów tylko wtedy, gdy te ostatnie zrealizują roboty budowlane lub usługi, odnośnie do których takie zdolności są niezbędne" (podobnie w art. $63 \S 2$ p.c.r.) ${ }^{76}$.

Wprowadzono również nowy art. $63 \S 6$ p.c.r., zgodnie z którym w przypadku zamówień na roboty budowlane, usługi lub dostawy obejmującej prace dotyczące rozmieszczenia lub instalacji zamawiający może wymagać, aby pewne kluczowe zadania były wykonywane bezpośrednio - gdy oferta jest składana przez grupę wykonawców - przez uczestnika tej grupy wykonawców, co jest implementacją art. 62 ust. 2 dyrektywy klasycznej. Należy także zwrócić uwagę na nowy art. 63 § p.c.r., w myśl którego zamawiający może - w przypadku wykonawcy polegającego na zdolnościach innych podmiotów (a więc także konsorcjum polegającego na potencjale konsorcjantów) w celu spełnienia kryteriów odnoszących się do sytuacji ekonomicznej i finansowej - wymagać od tego wykonawcy i podmiotów przyjęcia solidarnej odpowiedzialności za wykonanie zamówienia, co może być odpowiedzią na sugestię wynikającą z motywu piętnastego preambuły do dyrektywy klasycznej.

Co do wnoszenia odwołania na decyzję zamawiającego, brak jest w prawie brytyjskim przepisów wymagających od członków konsorcjum wprost wspólnego działania. W poprzednim stanie prawnym obowiązywał art. 28 § stanowiący, że pojęcie „wykonawca” obejmuje każdego członka konsorcjum. Uznawano zatem, że każdy członek może co do zasady wnosić samodzielnie jakiekolwiek skargi regulowane tym aktem prawnym. W związku z brakiem odpowiednika tego przepisu w nowej regulacji możliwość samodzielnego wnoszenia odwołania pozostaje niejasna, niemniej, jak wynika z wyroku Europejskiego Trybunału Sprawiedliwości w sprawach C-145/08 i C-149/08, Club Hotel Loutraki A.E. ${ }^{77}$, dyrektywa odwoławcza wymaga dopuszczenia poszczególnych członków konsorcjum do wnoszenia roszczeń odszkodowawczych.

75 Wyrok TS z dnia 18 lipca 2007 r. w sprawie C-399/05, Komisja v. Republika Grecji, ECR 2007, s. I-00101.

76 S. Arrowsmith, op. cit., s. 1215.

77 Wyrok TS z dnia 6 maja 2010 r. w sprawach połączonych C-145/08 i C-149/08, Club Hotel Loutraki A.E., Athinaiki Techniki A.E. i Evangelos Marinakis v. Ethniko Symvoulio Radiotileorasis i Ypourgos Epikrateias, ECR 2010, s. I-04165. 
Udziat konsorcjum w postępowaniu... $\mid 325$

\section{Konsorcjum we francuskim prawie zamówien publicznych}

\section{Konsorcjum w ogólności}

We Francji instytucja konsorcjum, uznawana za podrodzaj joint venture, ma istotne znaczenie teoretyczne i praktyczne. Francuski system prawny nie przewiduje definicji i nie posługuje się w sposób jednoznaczny pojęciem joint venture albo konsorcjum (groupements momentanés d'entreprises). Joint venture to raczej pojęcie ekonomiczne stosowane do pewnego typu kooperacji cechującej się wspólnym celem i korzyściami, nie zaś pojęcie prawne ${ }^{78}$.

Podobnie jak w systemie polskim i brytyjskim, francuskie konsorcjum to umowa kooperacyjna, której charakter jest czysto zobowiązaniowy i która nie pociąga za sobą utworzenia podmiotu trzeciego. Konsorcjum nie ma osobowości prawnej ani zdolności sądowej. Umowa jest zawierana między dwiema lub większą liczbą osób fizycznych bądź prawnych, które zobowiązują się do wykonania pewnych prac w celu zrealizowania wspólnego projektu. W praktyce kluczowe elementy konsorcjum to:1) wspólny cel wielu podmiotów, 2) realizacja konkretnych i określonych prac, 3) współpraca każdej strony polegająca na wykonaniu części prac ${ }^{79}$.

Umowa konsorcjalna nie jest wprost uregulowana przez francuskiego ustawodawcę, jest jednak dopuszczalna w świetle zasady swobody umów (wyinterpretowanej z art. 6 i art. 1134 francuskiego Kodeksu cywilnego ${ }^{80}$ ) i z tego powodu jej konstrukcja jest kształtowana w oparciu o stosowanie ogólnych zasad prawa kontraktów (przede wszystkim art. 1101 francuskiego Kodeksu cywilnego, na podstawie którego „kontraktem jest umowa, przez którą jedna lub kilka osób zobowiązują się względem jednej, lub kilku innych osób, do dania, czynienia, lub nieczynienia jakiejś rzeczy”). Konstrukcja umowy konsorcjalnej jest ponadto kształtowana przez judykaturę i doktrynę. Jedną z zasad dotyczących tego rodzaju kontraktu jest równość między stronami. Oznacza to, że umowa konsorcjum nie powinna być stosowana i może zostać podważona przez sąd w przypadku utworzenia konsorcjum przez podmiot, który kieruje lub w istotnym stopniu sprawuje kontrolę nad pozostałymi konsorcjantami. Tak będzie w sytuacji, gdy partnerzy nie są autonomiczni, w dodatku świadczenia, do których są zobowiązani, nie są równe, a najważniejsze uprawnienia zostały powierzone jednemu członkowi lub jedynie kilku członkom konsorcjum $\mathrm{z}$ wyłączeniem pozostałych ${ }^{81}$.

78 I. Hewitt, op.cit., s. 403.

79 D.M. Parrilli, Barriers and Enablers for SME Extended and Dynamic Clustering, Legal Barriers and Enablers, Brussels 2008, s. 16-17.

80 Code civil, wersja skonsolidowana z 17 października 2015 r., www.legifrance.gouv.fr [dostęp: 30.06.2016].

81 D.M. Parrilli, op. cit., s. 17. 
Wskazuje się też, że umowa konsorcjalna musi uwzględniać wszelkie ogólne reguły prawa kontraktów, np. zasadę ochrony porządku publicznego, reguły odnoszące się do zdolności do czynności prawnych partnerów, reguły dotyczące ważności wyrażenia zgody na zobowiązanie. Umowa konsorcjalna, w przeciwieństwie do umowy spółki handlowej, nie musi być sporządzona w języku francuskim. Jedynie w przypadku sporu przed francuskim sądem wymagane będzie tłumaczenie umowy przygotowane przez tłumacza przysięgłego. Nie wymaga się również sporządzenia umowy przed notariuszem ani jakiejkolwiek rejestracji. Strony mogą poddać umowę prawu francuskiemu lub jakiemukolwiek prawu obcemu, chyba że jedynym celem takiego działania jest uniknięcie stosowania francuskich norm bezwzględnie wiążących. Strony mogą również zamieścić w umowie klauzulę prorogacyjną, jednak egzekucja wyroków sądów spoza UE wymaga uznania przez francuski sąd (exequatur) ${ }^{82}$.

Jeśli chodzi o podmioty mogące być stronami umowy, to nie ma wątpliwości, że moga nimi być zarówno osoby fizyczne, jak i osoby prawne. Jeśli w danym przypadku jednym z kluczowych elementów kontraktu jest intuitus personae (co oznacza, że cechy właściwe dla każdego z członków są istotnym powodem, dla którego inni członkowie zawierają umowę), to możliwe jest również rozciągnięcie tej koncepcji na osoby prawne i używanie wyrażenia intuitus frmae lub intuitus societatis i wyłączenie lub ograniczenie możliwości zmian podmiotowych. W każdym razie nie ma ograniczeń co do liczby konsorcjantów, byle były to przynajmniej dwie osoby. Członkowie konsorcjum mogą skutecznie uzgodnić między sobą w umowie, że jeden z nich uczestniczy w przedsięwzięciu bez ponoszenia jakiegokolwiek ryzyka, straty czy wynagrodzenia, np. gdy uczestniczy w konsorcjum jedynie jako podmiot zarządzający (lider). Nie ma również ograniczeń co do przynależności państwowej konsorcjantów ${ }^{83}$.

$\mathrm{Z}$ prawnego punktu widzenia cel umowy może być dowolny, byle był zgodny z prawem. W praktyce wrażliwą kwestią, która może wpływać na zastosowanie tego rodzaju umowy do kooperacji między MŚP, jest przedmiot współpracy. Francuskie konsorcjum wydaje się właściwą formą współpracy, jeśli cel kooperacji jest konkretnie określony i składa się z realizacji poszczególnych prac czy świadczeń. Innymi słowy, jeśli grupa MŚP chciałaby dzielić zasoby grupy w celu współpracy w szerszy sposób (np. wspólna produkcja, marketing, badania i rozwój), francuskie konsorcjum prawdopodobnie nie jest najwłaściwszą umową dla ich potrzeb. Nadaje się ono bowiem do dostatecznie sprecyzowanych, zwykle pojedynczych projektów ${ }^{84}$.

82 F. Gonter, A. Veil, Joint ventures in France: overview, "Practical Law" 2015.

83 Ibidem.

84 D.M. Parrilli, op. cit., s. 17. Autor podaje przykład grupy MŚP chcącej uczestniczyć w prywatnym przetargu na wybudowanie nowej siedziby dla kontrahenta zewnętrznego (inwestora). Podmioty te muszą podzielić się zasobami, żeby wygrać przetarg i pomyślnie ukończyć pracę. Zawierają więc umowę konsorcjalną, która określa ich wzajemne zobowiązania. Każdy z nich będzie uczestniczył w projekcie ze swymi umiejętnościami i kompetencjami, i wniesie wkład 
Biorąc zaś pod uwagę długotrwałość współpracy, choć przedmiot umowy konsorcjalnej jest potencjalnie nieograniczony, to umowa zawsze będzie ograniczona w czasie - okres jej trwania nie może być dłuższy niż czas osiągnięcia wspólnego celu. Strony chcące założyć konsorcjum podlegające prawu francuskiemu powinny być tego świadome i muszą rozważnie zdecydować, do jakiego stopnia i jak długo chcą wspólpracować. Innymi słowy, muszą sprawdzić, czy chcą ograniczyć swoje wysiłki do jednego określonego projektu, czy też stworzyć bardziej stabilne relacje ${ }^{85}$.

Należy zauważyć, że francuskie prawo zabrania kreowania zobowiązań wieczystych. Stąd strony umowy zawartej na czas nieoznaczony mogą wypowiedzieć ją w każdym momencie ( $z$ ewentualnym okresem wypowiedzenia, jeśli taki ustalono). W praktyce umowa konsorcjalna zazwyczaj reguluje przypadki skutkujące jej automatycznym wygaśnięciem, choć kwestia ważności klauzul skutkujących rozwiązaniem umowy jest wciąż kontrowersyjna w systemie francuskim. Oczywiście nie jest wymagana żadna zgoda na wygaśniecie stosunku konsorcjalnego ze strony organu publicznego ${ }^{86}$.

\section{Zgrupowanie interesów gospodarczych}

We francuskim porządku prawnym od konsorcjum należy odróżnić zgrupowanie interesów gospodarczych (groupement d'intérêt économique, GIE), które pojawiło się we francuskim Ordonnance nr 61-821 z 23 września 1967 r. ${ }^{87}$ Zgrupowanie interesów gospodarczych może być alternatywą dla umowy konsorcjum, ze względu na podobne cechy, takie jak elastyczność struktury (w tym dobrowolność stworzenia kapitału założycielskiego, swoboda określenia reguł podejmowania decyzji) i korzyści wynikające z transparentności podatkowej. Bywają one wykorzystywane do dzielenia kosztów w grupie ${ }^{88}$.

Instytucja ta obecnie regulowana jest we francuskim Kodeksie handlowym z $2001 \mathrm{r}^{89}$ Zgodnie $z$ art. 1 Ordonnance i aktualnego art. L251-1 Kodeksu handlowego „dwie lub więcej osób prawnych lub fizycznych może utworzyć zgrupowanie interesów gospodarczych na czas określony. Celem zgrupowania jest ułatwianie lub rozwinięcie działalność gospodarczej ich członków, poprawa lub podwyższenie wyników ich działalności; nie jest nim zaś realizacja korzyści dla samej siebie. Jej działalność musi być związana z działalnością gospodarczą jej członków i może mieć wobec niej jedynie pomocniczy charakter”. W literaturze wskazuje się, że zgrupowanie interesów gospodarczych jest

dla osiągnięcia wspólnego celu. Kiedy cel zostanie osiągnięty, konsorcjum nie będzie miało więcej powodów do istnienia, w konsekwencji umowa wygaśnie, a konsorcjum przestanie istnieć.

85 Ibidem, s. 18.

86 F. Gonter, A. Veil, op. cit.

87 Ordonnance nr 67-821 z 23 września 1967 r. o zgrupowaniu interesów ekonomicznych, http:// www.legifrance.gouv.fr [dostęp: 30.06.2016].

88 I. Hewitt, op.cit., s. 406; F. Gonter, A. Veil, op. cit.

89 Code de commerce, wersja skonsolidowana z 1 kwietnia 2016 r., www.legifrance.gouv.fr [dostęp: 30.06.2016]. 
formą pośrednią między spółką osobową wraz z ochronnymi przepisami prawa spółek (np. francuskiej ustawy o spółkach handlowych z 24 lipca $1966 \mathrm{r}^{90}$ ) a umową nienazwaną, wykreowaną w oparciu o swobodę umów, zważywszy, że elastyczność przyjętego stosunku prawnego pozostaje - w danym przypadku - dla uczestników wciąż istotną wartością. Sukces tej formy prawnej zachęcił Komisję do użycia jej jako podstawy do stworzenia rozporządzenia o europejskim zgrupowaniu interesów gospodarczych ${ }^{91}$, przy czym sukcesu i popularności francuskiej formy prawnej nie udało się powtórzyć na poziomie europejskim. Patrząc z innej perspektywy, można powiedzieć, że zgrupowanie interesów gospodarczych jest hybrydowym podmiotem łączącym cechy stowarzyszenia, tj. association (regulowanego przez francuską ustawę z 1 lipca $1901 \mathrm{r}^{92}$ ) i spółki osobowej39.

Jeśli chodzi o kształt prawny tej instytucji, to zgrupowanie ma osobowość prawną. Członkowie zgrupowania odpowiadają solidarnie i osobiście za jego długi w sposób nieograniczony. Do założenia GIE GIE nie jest obowiązkowy kapitał założycielski mogący pełnić rolę gwarancji zaspokojenia potencjalnych wierzycieli zgrupowania w przypadku niewypłacalności członków. Aby zapobiec nieuczciwym praktykom transferu długów, wprowadzono zakaz przepisywania na GIE długów jego członków. Zarządzający zgrupowaniem dysponuje pełną możliwością reprezentacji i dokonywania czynności prawnych na rachunek zgrupowania, co sprzyja szybkości i elastyczności działań. GIE ulega automatycznemu rozwiązaniu, gdy przestaje mieć więcej niż jednego członka ${ }^{94}$.

\section{Spółka cywilna}

Od konsorcjum należy odróżnić dwa rodzaje spółek objętych regulacją francuskiego prawa cywilnego: spółkę cywilną (société civile), uregulowaną w art. 1832-1870 francuskiego Kodeksu cywilnego, i spółkę udziałową (société en participation), uregulowaną w art. 18711873. Od konsorcjum oddzielić powinno się także konstrukcję szczególnego rodzaju, którą jest „spółka wynikająca z okoliczności faktycznych” (société de fait). Francuska spólka cywilna musi posiadać statut podlegający rejestracji w rejestrze handlowym i spółek (Régistre du commerce et des sociétés). Spółka udziałowa nie jest rejestrowana i jest nazywana spółką cichą (société en participation), nie posiada osobowości prawnej. Natomiast

90 Loi nr 66-537 z 24 lipca 1966 r. o spółkach handlowych, www.legifrance.gouv.fr [dostęp: 30.06. 2016].

91 Rozporządzenie Rady (EWG) nr 2137/85 z dnia 25 lipca 1985 r. w sprawie europejskiego ugrupowania interesów gospodarczych (EUIG) z dnia 25 lipca 1985 r. (Dz.Urz. UE L nr 199, s. 1).

92 Loi z 1 lipca 1901 r. odnoszące się do umowy stowarzyszenia, wersja skonsolidowana z 12 marca 2015 r., www.legifrance.gouv.fr [dostęp: 30.06.2016].

93 D.M. Parrilli, op. cit., s. 24.

94 M. Sokołowski, Europejskie Zgrupowanie Interesów Gospodarczych w prawie polskim, Warszawa 2012, s. 1-3. 
co do spółki faktycznie utworzonej, to stosuje się wobec niej przepisy rozdziału Kodeksu cywilnego o spółkach ${ }^{95}$.

Istnieje ryzyko, że konkretna umowa konsorcjalna zostanie zakwalifikowana jako umowa spółki wynikająca z okoliczności faktycznych. Francuskie sądy uważają, że obecność wkładów i podziału zysków lub strat jest dowodem na istnienie spółki. Sąd może się oprzeć nie tylko na treści umowy, ale również na późniejszym postępowaniu stron umowy konsorcjalnej. W takim przypadku do konsorcjum znajdą zastosowanie reguły odnoszące się do spółki cywilnej, a ponadto mogą wystąpić istotne konsekwencje podatkowe ${ }^{96}$.

\section{Podwykonawstwo}

Należy również zwrócić uwagę na odmienność instytucji podwykonawstwa od konsorcjum, zwłaszcza na gruncie prawa zamówień publicznych, gdzie różnice mogą ulec pewnemu zatarciu (w szczególności przy konsorcjum reprezentowanym na zewnątrz jedynie przez lidera). Jako zasadniczą różnicę podaje się odmienność w określeniu stron umowy zamówieniowej (umowy z inwestorem). Francuski Kodeks zamówień publicznych nie zawiera definicji podwykonawstwa. Definicja podwykonawstwa (sous-traitance) znajduje się natomiast $\mathrm{w}$ ustawie dotyczącej podwykonawstwa z 31 grudnia 1975 r. ${ }^{97}$ Zgodnie z jej art. 1 podwykonawstwo jest stosunkiem, przez który przedsiębiorca (wykonawca) powierza na swoją odpowiedzialność innej osobie, zwanej podwykonawcą, wykonanie całości lub części umowy lub części umowy w sprawie zamówienia publicznego zawartej z zamawiającym. Powierzenie podwykonawcy wykonania zamówienia publicznego jest możliwe jedynie w części, niemożliwe zaś w całości. Jak stanowi art. 112 francuskiego Kodeksu zamówień publicznych ${ }^{98}$, wykonawca w zamówieniach publicznych dotyczących robót budowlanych (marché public de travaux), usług (marché public de services) lub przemysłu (marché industriel) mógł podzlecić wykonanie pewnych części zamówienia pod warunkiem otrzymania od zamawiającego zgody na każdego podwykonawcę oraz na jego warunki zapłaty ${ }^{99}$. Obecnie przepisy dotyczące podwykonawstwa znajdują się w art. 62 Ordonnance nr 2015-899 i w art. 133-137 dekretu 2016-360, o których będzie mowa dalej.

95 I. Hasińska, op. cit., s. 46-49.

96 F. Gonter, A. Veil, op. cit.

97 Loi nr 75-1334 z 31 grudnia 1975 r. odnoszące się do podwykonawstwa, wersja skonsolidowania z 10 sierpnia 2010 r., www.legifrance.gouv.fr [dostęp: 30.06.2016].

98 Code des marchés publics (édition 2006), wersja skonsolidowana z 1 października 2015 r., www. legifrance.gouv.fr [dostęp: 30.06.2016], dalej k.z.

99 E. Figura-Góralczyk, Z problematyki podwykonawstwa w zamówieniach publicznych na tle prawnoporównawczym, „Prawo Zamówień Publicznych”2013, nr 1, s. 23. 


\section{Regulacja udziału konsorcjum w postępowaniu zamówieniowym}

$\mathrm{Z}$ dniem 1 kwietnia 2016 r. weszły w życie akty prawne wdrażające nową dyrektywę klasyczną i sektorową i zastępujące dotychczasowe regulacje, mianowicie Ordonnance nr 2015-899 z 23 lipca 2015 r. w sprawie zamówień publicznych ${ }^{100}$ i akty wykonawcze w postaci Décret nr 2016-360 z 25 marca 2016 r. w sprawie zamówień publicznych ${ }^{101}$ i Décret nr 2016-361 z 25 marca 2016 r. w sprawie zamówień w dziedzinie obronności i bezpieczeństwa ${ }^{102}$. Jednocześnie z dniem 1 kwietnia 2016 r. weszły w życie Ordonnance Nr 2016-62 z 29 stycznia 2016 r. w sprawie umowy koncesyjnej ${ }^{103}$ i wykonawczy Décret Nr 2016-86 z 1 lutego 2016 r. w sprawie umowy koncesyjnej ${ }^{104}$ wdrażające dyrektywę koncesyjną. Przed implementacją dyrektyw francuskie zamówienia publiczne były regulowane przez wiele różnych aktów, z których podstawowym był Kodeks zamówień publicznych z 2006 r. Umowy koncesyjne i umowy partnerstwa publiczno-prywatnego były regulowane odrębnymi przepisami.

We francuskiej literaturze podkreśla się rolę konsorcjów i innego rodzaju tymczasowych zgrupowań w kontekście wspierania dostępu MŚP do rynku zamówień publicznych. Alternatywne sposoby to podział zamówienia na części i dopuszczenie instytucji podwykonawstwa. Konsorcjalna forma wspólpracy jest najbardziej odpowiednia dla małych przedsiębiorstw niemających zdolności do realizacji całego zamówienia, a mogących zsumować np. swoje zasoby ludzkie i materialne z innymi podobnymi podmiotami. Nie zawsze bowiem możliwa jest formuła podziału zamówienia na odrębne mniejsze części, jak np. przy zamówieniach centralnych (globalnych), dla których wymaga się technicznej spójności, czy też podział byłby nieuzasadniony finansowo. Francuskie sądy administracyjne potwierdzały, że możliwe jest stworzenie konsorcjum składającego się z przedsiębiorców o różnych kwalifikacjach. Poprzez umożliwienie udziału w postępowaniu zamówieniowym grupom wykonawców realizowana jest zasada swobodnego dostępu do zamówień publicznych ${ }^{105}$.

Reguły odnoszące się do grup wykonawców zostały włączone do art. 45 dekretu 2016360. Zasadniczo są one potwórzeniem treści dotychczasowych przepisów o grupach wykonawców zawartych w art. 51 uchylonego Kodeksu zamówień, choć redakcja przepisów

100 Ordonnance nr 2015-899 z 23 lipca 2015 r. w sprawie zamówień publicznych, www.legifrance. gouv.fr [dostęp: 30.06.2016], dalej ordynans 2015-899.

101 Décret nr 2016-360 z 25 marca 2016 r.w sprawie zamówień publicznych, www.legifrance.gouv. fr [dostęp: 30.06.2016], dalej dekret 2016-360.

102 Décret nr 2016-361 z 25 marca 2016 r. w sprawie zamówień w dziedzinie obronności i bezpieczeństwa, ww.legifrance.gouv.fr [dostęp: 30.06.2016], dalej dekret 2016-361.

103 Ordonnance nr 2016-62 z 29 stycznia 2016 r. w sprawie umowy koncesyjnej, www.legifrance. gouv.fr [dostęp: 30.06.2016].

104 Décret nr 2016-86 z 1 lutego 2016 r. w sprawie umowy koncesyjnej, www.legifrance.gouv.fr [dostęp: 30.06.2016].

105 Code des Marchés Publics, red. F. Llorens, P. Soler-Couteaux, Paris 2015, s. 833-864. 
uległa pewnej modyfikacji. Z kolei art. 44 (poprzednio art. 52 k.z.) wspomina o ocenie zdolności grupy wykonawców.

Odpowiednikiem art. 44 i 45 dekretu 2016-360 są w obszarze zamówień w dziedzinie obronności art. 36 i 38 dekretu 2016-361. W toku każdego postępowania zamówieniowego regulowanego przez Kodeks zamówień konieczne jest przestrzeganie zasady swobodnego dostępu do zamówień publicznych, równego traktowania wykonawców i transparentności procedur. Kodeks nie posługuje się wprost pojęciem konsorcjum, ale pojęciem grupy. Przez to pojęcie należy rozumieć zarówno grupy mogące mieć osobowość prawną (np. stowarzyszenie, spółka, zgrupowanie interesów gospodarczych, europejskie zgrupowania interesów gospodarczych), jak i tzw. grupę tymczasową (groupements momentanés d'entreprises), czyli konsorcjum.

Zgodnie $\mathrm{z}$ art. 45 dekretu 2016-360 grupa wykonawców może uczestniczyć w procedurze ubiegania się o udzielenie zamówienia publicznego. Do samego złożenia wniosku lub oferty zamawiający nie może żądać od grupy przyjęcia określonej formy prawnej. Stąd wykonawcy mogą złożyć ofertę, działając zarówno jako „grupa wspólna” (groupement conjoint), jak i "grupa solidarna” (groupement solidaire). Zamawiający może jednak wymagać od konsorcjantów przyjęcia określonej formy prawnej już po udzieleniu zamówienia w zakresie niezbędnym do jego prawidłowego wykonania. W takim przypadku zamawiający precyzuje ten wymóg w dokumentacji przetargowej.

W nowym art. 45 dekretu 2016-360 usunięto zastrzeżenie z art. 51 k.z. o zgodności z regulacjami odnoszącymi się do swobodnego ustalania cen i konkurencji. Nie wydaje się, aby zabieg ten miał inny charakter niż jedynie redakcyjny. Aktualne pozostają uwagi formułowane na tle poprzedniego stanu prawnego, że ze względu na tego rodzaju uregulowanie instytucje zamawiające nie mogą zabronić wykonawcom tworzenia grup. Podkreślano, że Francja przyjęła bardzo liberalne stanowisko w sprawie ograniczeń prawa konkurencji dotyczących udziału konsorcjów w postępowaniu zamówieniowym. Mianowicie nawet gdyby podmioty mogły uczestniczyć w postępowaniu zamówieniowym jako samodzielni oferenci (spełniając samodzielnie wszystkie konieczne warunki), to byłyby one uprawnione do stworzenia konsorcjum ofertowego tak długo, jak cel lub skutek grupowego działania nie stanowiłby ograniczenia konkurencji. To podejście efektywnie obciąża koniecznością udowodnienia szkodliwego skutku grupowej współpracy instytucję zamawiającą, która zamierzałaby nałożyć jakiegoś rodzaju ograniczenia ${ }^{106}$.

Należy zwrócić uwagę, że francuskie przepisy zamówieniowe wyróżniają dwa rodzaje grup wykonawców. W grupie wspólnej (groupement conjoint) każdy z członków odpowiada jedynie za tę część zamówienia, która została mu powierzona. Zamówienie powinno móc się podzielić na odrębne części, które można powierzyć poszczególnym konsorcjantom. W grupie solidarnej (groupement solidaire) każdy członek grupy odpo-

106 G.L. Albano, G. Spagnolo, M. Zanza, op. cit., s. 348. 
wiedzialny jest za wykonanie całego zamówienia, ponosi bowiem odpowiedzialność solidarną z pozostałymi uczestnikami zgrupowania. Nie ma tu znaczenia, czy zamówienie da się podzielić na odrębne części. W obu modelach wyznaczany jest lider zgrupowania (reprezentant), który reprezentuje grupę wobec instytucji zamawiającej i koordynuje zadania wykonywane przez członków grupy. W modelu wspólnej grupy możliwe jest przyjęcie solidarnej odpowiedzialności lidera za całe zamówienie w umowie z zamawiającym. Wspólna grupa jest bardziej odpowiednia dla małych projektów, gdy zamawiający nie potrzebuje zobowiązania każdego z członków grupy do przyjęcia odpowiedzialności za wykonanie całego zamówienia. Grupa solidarna jest korzystniejsza dla zamawiającego, który może dochodzić roszczeń od każdego członków z grupy ponoszących solidarną odpowiedzialność. W składanej dokumentacji konsorcjanci powinni określić liczbę i szczegółowy podział świadczeń, które każdy z członków grupy jest zobowiązany wykonać, albo wszystkie świadczenia, które członkowie grupy solidarnie podejmują się wykonać. Wnioski i oferty są przedkładane przez wszystkich wykonawców z grupy albo przez pełnomocnika, jeżeli posiada niezbędne uprawnienia (pełnomocnictwo) do reprezentowania tych wykonawców w toku postępowania zamówieniowego.

W poprzednim stanie prawnym przepis wprost stanowił, że jeden wykonawca nie może reprezentować więcej niż jednej grupy przy tym samym zamówieniu. W obecnym stanie prawnym nie jest wykluczone, że taka praktyka będzie w pewnych sytuacjach dopuszczona. Wciąż jednak zamawiający w dokumentach określających reguły postępowania (dokumentacji przetargowej) może zabronić oferentom składania kilku ofert na to samo zamówienie lub na jedną z jego części przy jednoczesnym działaniu jako indywidualny oferent i członek grupy lub grup wykonawców, a także składania ofert w ramach kilku grup.

W postępowaniach kilkuetapowych skład grupy nie powinien być zmieniany w okresie między datą złożenia wniosku o dopuszczenie do udziału w postępowaniu a datą podpisania umowy w sprawie zamówienia publicznego. Jednak w przypadku restrukturyzacji (np. nabycia przedsiębiorstwa, przejęcia, fuzji) albo wykazania przez grupę, że członek nie jest w stanie wykonać jego zadania z przyczyn, które nie są spowodowane przez niego, grupa może zwrócić się do instytucji zamawiającej o zezwolenie na dalszy udział w postępowaniu zamówieniowym bez brakującego wykonawcy, przedstawiając w razie potrzeby do akceptacji zamawiającego jednego lub więcej podwykonawców. Zamawiający podejmuje decyzję w sprawie tego wniosku po zbadaniu kompetencji zawodowych, technicznych i finansowych wszystkich członków grupy tak przekształconej, a w stosownych przypadkach także podwykonawców przedstawionych do akceptacji.

Powodem tworzenia konsorcjów wykonawców jest zazwyczaj zamiar połączenia zasobów poszczególnych członków w celu spełnienia warunków udziału w postępowaniu wymaganych przez zamawiającego. Oferenci muszą bowiem udowodnić swoją zdolność do kontynuowania aktywności zawodowej, sytuację ekonomiczną i finansową lub moż- 
liwości techniczne i zawodowe, np. poprzez system certyfikatów wystawianych przez profesjonalne organizacje, przez przedłożenie pisemnych oświadczeń o zadowalającym wykonaniu podobnych prac w przeszłości albo informacji ze sprawozdania finansowego. W myśl art. 44 dekretu 2016-360 ocena zdolności grupy jest dokonywana łącznie. Nie jest więc wymagane, aby każdy członek grupy miał samodzielnie wszelkie zasoby czy potencjał niezbędny do wykonania zamówienia ${ }^{107}$.

Zgodnie $\mathrm{z}$ art. 50 ordynansu 2015-899 w razie gdy przyczyny wykluczenia $\mathrm{z}$ procedury zamówieniowej leżą po stronie członka grupy, zamawiający żąda zastąpienia go przez podmiot niedający powodów do wykluczenia w ciągu 10 dni od otrzymania żądania przez reprezentanta grupy pod rygorem wykluczenia całej grupy z procedury.

W nawiązaniu do dyrektywy klasycznej dodano w art. 45 dekretu 2016-360 zastrzeżenie, że przy zamówieniach na roboty budowlane, usługi i dostawy obejmujące usługi lub prace dotyczące rozmieszczenia i instalacji zamawiający mogą wymagać, aby pewne kluczowe zadania były wykonywane bezpośrednio przez członka zgrupowania.

\section{Podsumowanie}

Powodem trudności w znalezieniu wspólnej definicji „konsorcjum” dla systemów prawnych państw członkowskich są znaczne różnice w regulacjach prawnych i praktyce kontraktowej. Ogólnie można powiedzieć, że w większości systemów prawnych uznaje się umowę konsorcjalną za jedną z bardziej elastycznych form kooperacji między podmiotami. W państwach common law treść umowy konsorcjalnej w bardzo szerokim zakresie zależy od woli stron. Natomiast w części systemów kontynentalnych umowa konsorcjum to specjalny typ umowy nazwanej normowanej przez przepisy względnie i bezwzględnie wiążące, gdzie swoboda kontrahentów jest znacznie mniejsza. Nawet w razie uregulowania umowy konsorcjum jako umowy nazwanej treść regulacji różni się istotnie w poszczególnych krajach ${ }^{108}$. Jednak w analizowanych systemach prawnych umowa konsorcjum pozostawała umową nienazwaną.

Zazwyczaj przy próbie opisania stosunku prawnego konsorcjum autorzy z różnych krajów łączą umowę konsorcjalną z joint venture bezudziałowym czy kontraktowanym (non-equity joint venture, contractual joint venture) lub strategicznym aliansem. Istotną cechą tych form kooperacji jest to, że nie pociągają one za sobą utworzenia nowego podmiotu. Nie jest natomiast cechą przesądzającą krótkoterminowy charakter współpracy w ramach konsorcjum. Choć w większości przypadków czas trwania stosunku konsorcjalnego łączony jest $\mathrm{z}$ wykonaniem określonego zadania, to nie jest wykluczone, że konsorcjum będzie wykorzystywane do działalności długoterminowej.

107 Ibidem, s. 339.

108 D.M. Parrilli, op. cit., s. 16. 
Porównując polskie regulacje $\mathrm{z}$ francuskimi, należy zwrócić uwagę na podział na grupy wspólne i solidarne w prawie francuskim. Ze względu na art. 141 p.z.p. w polskim systemie zamówień publicznych występuje jedynie odpowiednik tego drugiego modelu. W związku z tym niemożliwe byłoby wprowadzenie - na wzór francuski - szczególnej odpowiedzialności pełnomocnika konsorcjum (przyjmując, że jest jego uczestnikiem), skoro wszyscy konsorcjanci ponoszą solidarną odpowiedzialność za wykonanie umowy i wniesienie zabezpieczenia.

Patrząc zaś na brytyjskie rozwiązania, należy stwierdzić, że regulacja ta jest wciąż bardziej lakoniczna niż francuska. Odmiennie niż w ustawie polskiej i francuskiej, nie ma wymogu wyznaczenia pełnomocnika przez konsorcjantów. Jeżeli zaś chodzi o odpowiedzialność konsorcjantów wobec zamawiającego, to w 2015 r. wprowadzono uprawnienie po stronie zamawiającego polegające na możliwości narzucenia konsorcjantom solidarnej odpowiedzialności, co wydaje się rozwiązaniem lepszym niż obligatoryjna solidarna odpowiedzialność w każdym przypadku przewidziana w prawie polskim.

\section{Literatura}

Albano G.L., Spagnolo G., Zanza M., Regulating Joint Bidding in Public Procurement, "Journal of Competition Law and Economics" 2009, t. 5, nr 2.

Arrowsmith S., The Law of Public and Utilities Procurement. Regulation in the EU and UK, London 2014.

Babiarz S., Prawo zamówień publicznych. Komentarz, Warszawa 2013.

Baehr J., Zamawiający i wykonawcy, [w:] Prawo zamówień publicznych. Komentarz, red. T. Czajkowski, Warszawa 2007.

Bailey J., Construction Law, Abingdon 2011.

Chrząszcz A., Konsorcjum w zamówieniach publicznych, „Przegląd Prawa Handlowego” 2013, nr 7.

Code Des Marchés Publics, red. F. Llorens, P. Soler-Couteaux, Paris 2015.

Figura-Góralczyk E., Z problematyki podwykonawstwa w zamówieniach publicznych na tle prawno-porównawczym, „Prawo Zamówień Publicznych” 2013, nr 1.

Gałczyńska-Lisik K., Konsorcjum w świetle prawa zamówień publicznych, „Przegląd Prawa Handlowego" 2006, nr 10.

Gonter F., Veil A., Joint ventures in France: overview, Practical Law/el. 2015.

Grabarczyk M., Dostateczna wiedza i doświadczenie jako warunek ubiegania się o zamówienie publiczne, „Prawo Zamówień Publicznych”2014, nr 1.

Hasińska I., Charakter prawny spótki cywilnej na tle historycznym i prawnoporównawczym [praca doktorska], Wydział Prawa i Administracji Uniwersytetu im. Adama Mickiewicza w Poznaniu, 2013.

Hewitt I., Joint Ventures, London 2001. 
Hilla J., Prawne problemy funkcjonowania konsorcjum, „Radca Prawny” 2005, nr 5.

Horubski K., Kocowski T., Konsorcjum jako instrument wsparcia matych i srednich przedsiębiorców w systemie zamówień publicznych, [w:] Nowe podejscie do zamówień publicznych - zamówienia publiczne jako instrument zwiększania innowacyjności gospodarki i zrównoważonego rozwoju. Doświadczenia polskie i zagraniczne. Częśc I, red. J. Niczyporuk, J. Sadowy, M. Urbanek, Kazimierz Dolny 2011.

Horubski K., Zmiany sktadu konsorcjum w postęporwaniu o udzielenie zamówienia oraz na etapie wykonywania zamówienia, Wrocław 2012.

Horubski K., Kocowski T., Spetnianie warunków udziatu w postępowaniu przez wykonawców wspólnie ubiegających się o zamówienie, „Prawo Zamówień Publicznych” 2014, $\mathrm{nr} 1$.

Jerzykowski J., Glosa do wyroku SN z dnia 13 grudnia 1999 r., III CKN 478/98, „Monitor Prawniczy" 2001, nr 15.

Kalina-Nowaczyk M., Solidarna odpowiedzialnośc wykonawców za niewykonanie lub nienależyte wykonanie zamówienia publicznego, [w:] Odpowiedzialność cywilnoprawna w obrocie gospodarczym, red. A. Śmieja, Wrocław 2011.

Kańtor K., Wróblewska K., Umowa konsorcjum - konsekwencje w zakresie VAT, „Przegląd Podatkowy" 2015, nr 12.

Kocowski T., Wspólni zamawiający oraz wspólni wykonawcy w systemie zamówień publicznych, [w:] Zamówienia publiczne - stan obecny i perspektywy, red. T. Kocowski, J. Kaspryszyn, Wrocław 2012.

Kołaczyńska-Wyszogrodzka I., Petnomocnictwo a wspólne ubieganie się o udzielenie zamówienia publicznego, „Finanse Komunalne” 2007, nr 1.

Kowalewski E., Mogilski W., Gwarancja ubezpieczeniowa cztonka konsorcjum jako wadium w postepowaniu o uzyskanie przez konsorcjum zamówienia publicznego, „Wiadomości Ubezpieczeniowe”2014, nr 1.

Lic J., Konsorcjum w zamówieniach publicznych, „Prawo Zamówień Publicznych” 2008, $\mathrm{nr} 4$.

Makowski M., Gwarancja bankowa jako forma wniesienia wadium - kontrowersje interpretacyjne, „Prawo Zamówień Publicznych” 2008, nr 2.

May J., Dochodzenie roszczeń przez uczestników konsorcjum, „Prawo Zamówień Publicznych" 2015, nr 2.

Mucha A., Odpowiedzialnośc uczestników konsorcjum, „Internetowy Przegląd Prawniczy TBSP UJ” 2013, nr 13.

Muchowska-Zwara K., Prawne problemy funkcjonowania konsorcjów uczestniczących w obrocie regulowanym przez Prawo zamówień publicznych, Warszawa 2015.

Myrczek E., The art of drafting contracts - o podobienstwach i różnicach polskich umów i angielskich kontraktów, „Edukacja Prawnicza” 2008, nr 2.

Newsholme C., Groves P., Joint ventures in the UK: overview, Practical Law/el. 2015. 
336 | Adam Mickiewicz University Law Review

Norek E.A., Prawo zamówień publicznych. Komentarz, Warszawa 2009.

Opalski A., Umowy o wspólne przedsięwzięcie (joint venture), [w:] System prawa prywatnego, t. 9, Prawo zobowiqzań - umowy nienazwane, red. W. Katner, Warszawa 2015.

Parrilli D.M., Barriers and Enablers for SME Extended and Dynamic Clustering, Legal Barriers and Enablers, Brussels 2008.

Pokrzywniak J., Gwarancja na gruncie PZP, „Miesięcznik Ubezpieczeniowy”2014, nr 9.

Raczkiewicz Z., Konsorcja w ramach zamówień publicznych, „Prawo Zamówień Publicznych" 2009, nr 2.

Sokołowski M., Europejskie Zgrupowanie Interesów Gospodarczych w prawie polskim, Warszawa 2012.

Stecki L., Konsorcjum, Toruń 1997.

Strzępka J., Konsorcjum budowlane - wybrane zagadnienia prawne, „Monitor Prawniczy” 2012, nr 14.

Wiak J., Spetnienie warunków udziatu w postęporwaniu przez wykonawców wspólnie ubiegających się o udzielenie zamówienia publicznego, „Finanse Komunalne” 2012, nr 6.

Williams-Elegbe S., Fighting Corruption in Public Procurement. A Comparative Analysis of Disqualification or Debarment Measures, Oxford 2012.

Włodyka S., Spyra M., Umowy i porozumienia o wspótpracę przedsiębiorców (umowy kooperacyjne), [w:] System prawa handlowego, t. 5, Prawo umów handlowych, red. S. Włodyka, Warszawa 2014.

Włodyka S., Strategiczne umowy przedsiębiorców, Warszawa 2000.

Szostak R., Glosa do wyroku SN z dnia 13 grudnia 1999 r., III CKN 478/98, „Samorząd Terytorialny" 2001, nr 6.

Świstak R., Konsorcjum w świetle prawa zamówień publicznych-polemika, „Przegląd Prawa Handlowego" 2007, nr 3.

Zielińska E., Konsorcjum w procesie budowlanym w systemie polskiego i niemieckiego prawa prywatnego, [w:] Wptyw europeizacji prawa na instytucje prawa handlowego, red. J. Kruczalak-Jankowska, Warszawa 2013.

Zielińska E., Wspólna realizacja zamówienia publicznego - zagadnienia wybrane, „Prawo Zamówień Publicznych” 2015, nr 1.

Harmon CFEM Facades (UK) Ltd. v. The Corporate Officer of the House of Commons (2000) 2 L.G.L.R. 372.

Townsend v. Stone Toms \& Partners [1981], „Weekly Law Reports”1981, t. 1.

Wyrok SA w Warszawie z dnia 16 lutego 2000 r., I ACa 878/00, LEX nr 1681006.

Wyrok SN z dnia 13 grudnia 1999 r., III CKN 478/98, OSNC 2000, nr 6, poz. 118.

Wyrok TS z dnia 14 kwietnia 1994 r. w sprawie C-389/92, Ballast Nedam Groep, ECR 1994. 
Wyrok TS z dnia 18 grudnia 1997 r. w sprawie C-5/97, Ballast Nedam Groep v. Belgia, ECR 1997.

Wyrok TS z dnia 2 grudnia 1999 r. w sprawie C-176/98, Holst Italia SpA v. Comune di Cagliari, ECR 1999.

Wyrok TS z dnia 18 lipca 2007 r. w sprawie C-399/05, Komisja v. Republika Grecji, ECR 2007.

Wyrok TS z dnia 6 maja 2010 r. w sprawach połączonych C-145/08 i C-149/08, Club Hotel Loutraki A.E., Athi-naiki Techniki A.E. i Evangelos Marinakis v. Ethniko Symvoulio Radiotileorasis i Ypourgos Epikrateias, ECR 2010.

Wyrok TS z dnia 18 października 2012 r. w sprawie C-218/11, Észak-dunántúli Környezetvédelmi és Vízügyi Igazgatóság (Édukövízig), Hochtief Construction AG Magyarországi Fióktelepe v. Közbeszerzések Tanácsa Közbe-szerzési Döntőbizottság, ECLI EU C 2012, 643.

Wyrok Zespołu Arbitrów z dnia 19 marca 1998 r., UZP/ZO/0-108/98, ZPO 1998, nr 1, poz. 32.

Wyrok Zespołu Arbitrów z dnia 17 września 1998 r., UZP/ZO/0-756/98, ZPO 1998, nr 2, poz. 59.

Wyrok Zespołu Arbitrów z dnia 4 stycznia 1999 r., UZP/ZO/0-1185/98, www.uzp. gov.pl.

Wyrok Zespołu Arbitrów z dnia 12 stycznia 1999 r., UZP/ZO/0-1186/98, ZPO 1999, nr 1, poz. 11.

Wyrok Zespołu Arbitrów z dnia 6 kwietnia 1999 r., UZP/ZO/0-162/99, ZPO 1999, nr 1, poz. 92.

Wyrok Zespołu Arbitrów z dnia 11 maja 1999 r., UZP/ZO/0-253/99, ZPO 2000, nr 1, poz. 53.

Wyrok Zespołu Arbitrów z dnia 17 listopada 1999 r., UZP/ZO/0-1090/99, ZPO 1999, nr 2, poz. 210.

Wyrok Zespołu Arbitrów z dnia 8 lutego 2000 r., UZP/ZO/0-066/00, ZPO 2000, nr 2, poz. 31.

Wyrok Zespołu Arbitrów z dnia 9 marca 2000 r., UZP/ZO/0-133/00, ZPO 2000, nr 2, poz. 41.

Wyrok Zespołu Arbitrów z dnia 13 czerwca 2000 r., UZP/ZO/0-516/00, ZPO 2000, nr 2, poz. 124.

Wyrok Zespołu Arbitrów z dnia 16 czerwca 2000 r., UZP/ZO/0-537/00, ZPO 2000, nr 2, poz. 130.

Wyrok Zespołu Arbitrów z dnia 23 października 2000 r., UZP/ZO/0-1160/00, ZPO 2000, nr 3, poz. 126.

Wyrok Zespołu Arbitrów z dnia 23 listopada 2000 r., UZP/ZO/0-1350/00, ZPO 2000, nr 3, poz. 159. 
Wyrok Zespołu Arbitrów z dnia 27 listopada 2000 r., UZP/ZO/0-1361/00, ZPO 2000, nr 3, poz. 164 .

\section{SUMMARY}

\section{Participation of a consortium in the procedure for the award of public contract} with the examples of Poland, United Kingdom and France

The aim of the study is to compare regulations relating to consortia applying for public contracts in Polish, British and French law. Although it is impossible to find a common definition of a "consortium" for all EU members, due to the harmonization of rules concerning the functioning of the public procurement markets, the solutions adopted by member states are quite similar. However, there are also some specific regulations in individual countries. It is worth considering the usefulness of the adoption of similar solutions in other countries. In each analyzed country the author describes the general legal aspects of the functioning of a consortium in the legal system, then refers to similar legal institutions e.g. partnerships or subcontracting, and finally characterizes the regulation relating to the participation of the consortium in the procedure for the award of public contract.

Keywords: commercial law, consortium, public contracts

Marcin Czerwiński, Adam Mickiewicz University Poznań, Faculty of Law and Administration,Al. Niepodległości 53,61-714 Poznań, e-mail: marcin.czerwinski@amu.edu.pl. 